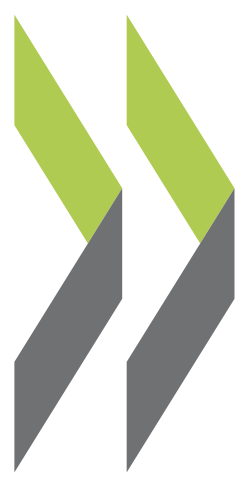

OECD Economics Department Working Papers No. 1257

\title{
Boosting export
}

performance in Portugal

\section{Jens Matthias Arnold}


Organisation de Coopération et de Développement Économiques

Organisation for Economic Co-operation and Development

17-Aug-2015

ECONOMICS DEPARTMENT

English - Or. English

BOOSTING EXPORT PERFORMANCE IN PORTUGAL

ECONOMICS DEPARTMENT WORKING PAPERS No. 1257

By Jens Arnold

OECD Working Papers should not be reported as representing the official views of the OECD or of its member countries. The opinions expressed and arguments employed are those of the author(s).

Authorised for publication by Robert Ford, Deputy Director, Country Studies Branch, Economics Department.

All Economics Department Working Papers are available at www.oecd.org/eco/workingpapers

JT03380841

Complete document available on OLIS in its original format

This document and any map included herein are without prejudice to the status of or sovereignty over any territory, to the delimitation of international frontiers and boundaries and to the name of any territory, city or area. 
OECD Working Papers should not be reported as representing the official views of the OECD or of its member countries. The opinions expressed and arguments employed are those of the author(s).

Working Papers describe preliminary results or research in progress by the author(s) and are published to stimulate discussion on a broad range of issues on which the OECD works.

Comments on Working Papers are welcomed, and may be sent to OECD Economics Department, 2 rue André Pascal, 75775 Paris Cedex 16, France, or by e-mail to eco.contact@oecd.org.

All Economics Department Working Papers are available at www.oecd.org/eco/workingpapers.

The statistical data for Israel are supplied by and under the responsibility of the relevant Israeli authorities. The use of such data by the OECD is without prejudice to the status of the Golan Heights, East Jerusalem and Israeli settlements in the West Bank under the terms of international law.

\section{(C) OECD (2015)}

You can copy, download or print OECD content for your own use, and you can include excerpts from OECD publications, databases and multimedia products in your own documents, presentations, blogs, websites and teaching materials, provided that suitable acknowledgment of OECD as source and copyright owner is given. All requests for commercial use and translation rights should be submitted to rights@oecd.org 


\section{ABSTRACT/RÉSUMÉ}

\section{Boosting Export Performance in Portugal}

In the years before the economic crisis, Portugal had low growth, a decline in export competitiveness and rising imbalances that included a large current account deficit and a strong expansion of the nontradable sector. Strengthening export performance is therefore one of the principal challenges for Portugal. A successful rebalancing of the economy is underway since Portugal started an ambitious structural reform programme in 2011, but more needs to be done to build on the recent export success. This includes both measures to improve competitiveness, such as reforms in energy and services sectors, and measures to boost productivity growth, such as tax reform, improving the performance of the judicial system and better public support for research and development. Given that exporting firms are typically the top performers in their industry, and have been so even before becoming exporters, it is important to avoid policies that could slow down the possibilities for high-performing firms to gain market share, such as the extension of collective wage agreements or the design of tax credits for research and development activities. Support for small enterprises should also be designed to benefit start-ups with a strong growth performance, as well as firms that are increasing their participation in international trade.

This Working Paper relates to the 2014 OECD Economic Survey of Portugal (www.oecd.org/eco/surveys/economic-survey-portugal.htm).

JEL classification: D2, F1, J3, J5, K2, K4, H2, L5

Keywords: Exporting, productivity, structural reform, competitiveness

$* * * * * * * * * * * * * *$

\section{Stimuler la performance à l'exportation au Portugal}

Pendant les années qui ont précédé la crise financière, la croissance a été faible au Portugal, la compétitivité des exportations a reculé et les déséquilibres se sont amplifiés, marqués notamment par un important déficit de la balance courante et une forte expansion du secteur des biens non échangeables. Renforcer les performances à l'exportation est donc l'un des principaux défis que le Portugal se doit de relever. Les premiers signes d'un rééquilibrage de l'économie sont apparus depuis que le Portugal a engagé un ambitieux programme de réformes structurelles en 2011, mais il reste encore à faire pour mettre à profit les succès récents à l'exportation. Il s'agit notamment de prendre à la fois des mesures destinées à améliorer la compétitivité-coût, par exemple des réformes dans les secteurs de l'énergie et des services, et des mesures visant à doper la hausse de la productivité, par exemple en adoptant une réforme fiscale, en améliorant les performances du système judiciaire et en renforçant le soutien public à la recherchedéveloppement. Étant donné que les entreprises exportatrices sont généralement celles qui, dans leur secteur d'activité, sont les plus performantes, et qu'elles l'étaient généralement déjà avant même de devenir exportatrices, il est important d'éviter toute politique qui pourrait avoir pour effet d'amoindrir les possibilités offertes aux entreprises très performantes de gagner des parts de marché, par exemple l'extension des accords de négociation collective ou la mise en place de crédits d'impôts pour la recherchedéveloppement. Par ailleurs, le soutien aux petites entreprises devrait être conçu de manière à bénéficier aux jeunes pousses en forte croissance plutôt qu'à de petites entreprises déjà parvenues à un stade de maturité.

Ce Document de travail se rapporte à l'Étude économique de l'OCDE du Portugal, 2014 (www.oecd.org/fr/eco/etudes/etude-economique-portugal.htm).

Classification JEL : D2, F1, J3, J5, K2, K4, H2, L5

Mots clefs : Exportations, productivité, réformes structurelles, compétitivité-coût 


\section{TABLE OF CONTENTS}

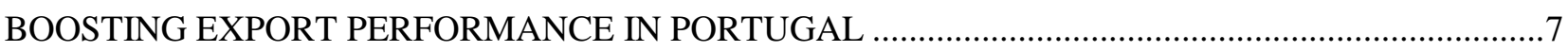

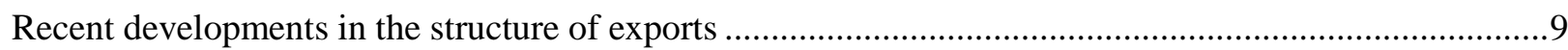

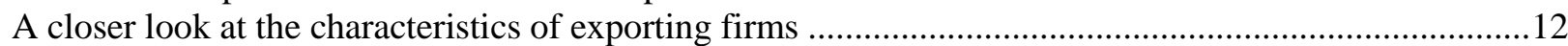

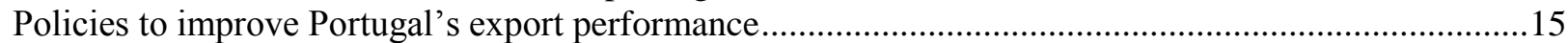

Access to intermediate production inputs from non-tradable sectors...................................................16

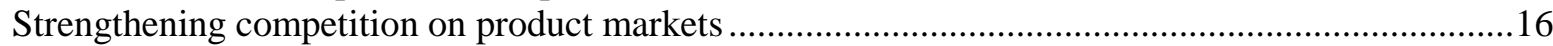

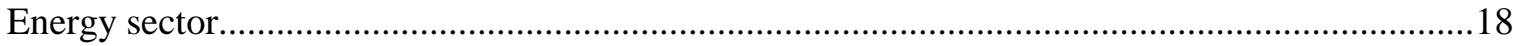

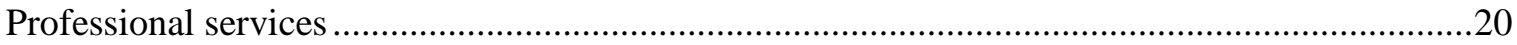

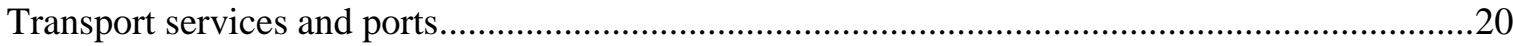

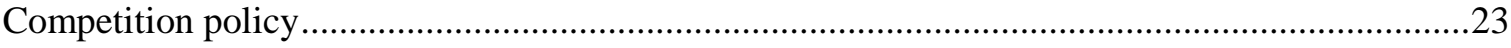

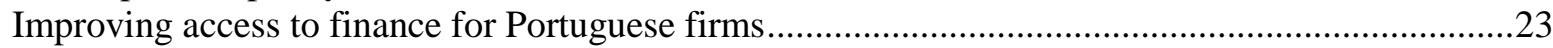

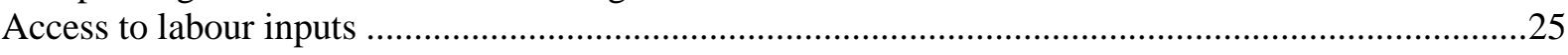

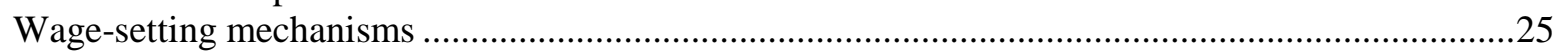

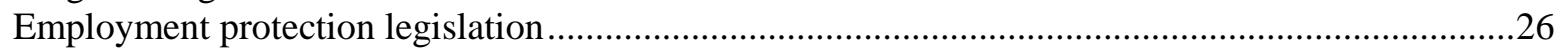

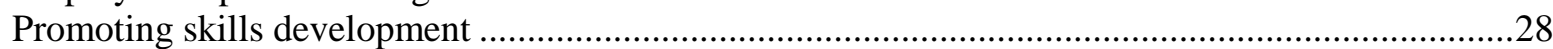

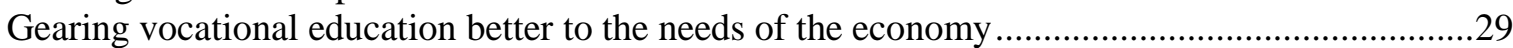

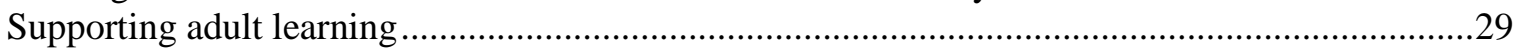

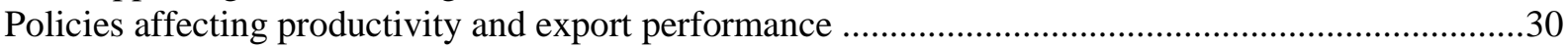

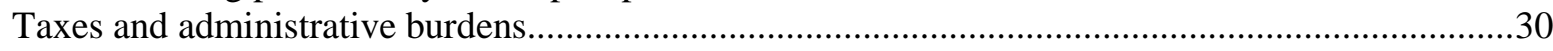

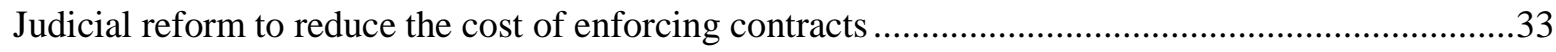

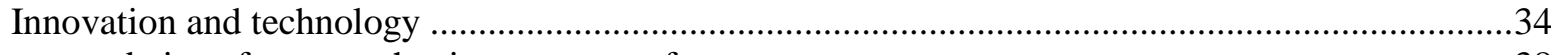

Recommendations for strengthening export performance …................................................................38

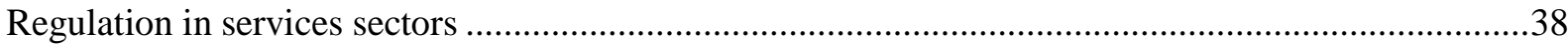

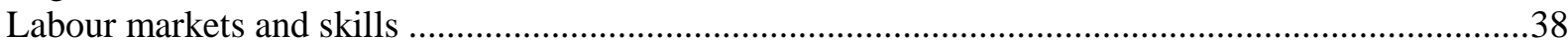

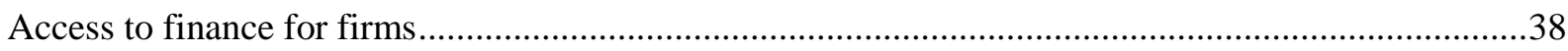

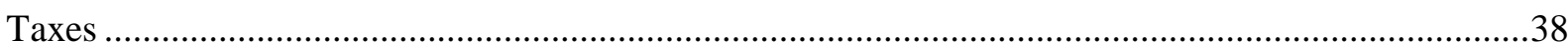

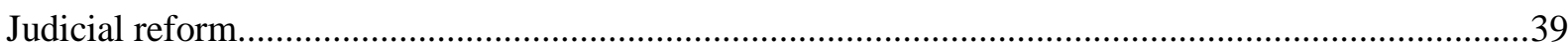

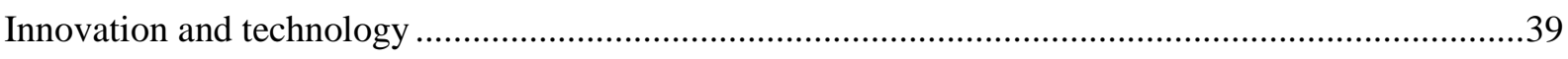

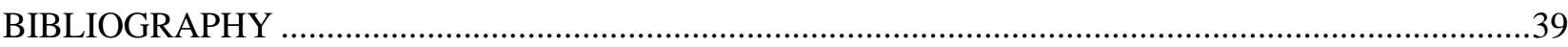

\section{Tables}

1. Basic characteristics of manufacturing firms by export status ....................................................13

\section{Figures}

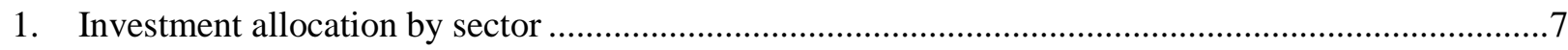

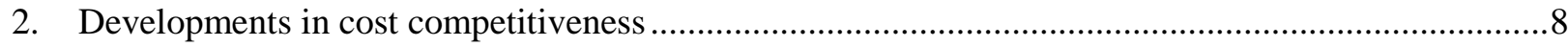




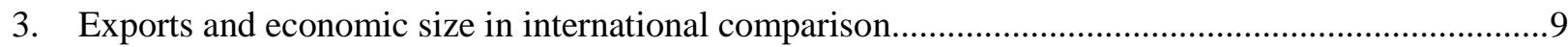

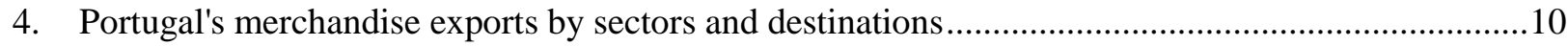

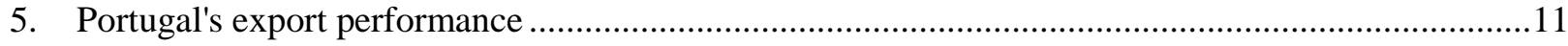

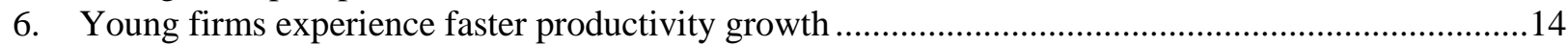

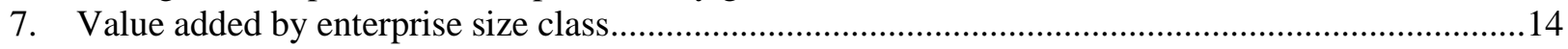

8. A simplified cost breakdown in tradable sectors .........................................................................15

9. Prices in non-tradable sectors have increased faster than in tradable sectors ...................................16

10. Aggregate product market regulation indicator .......................................................................

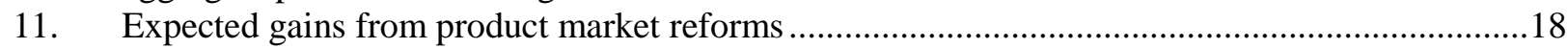

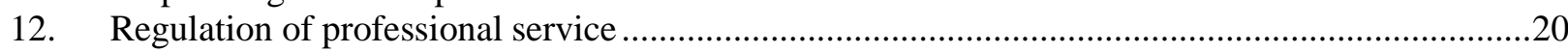

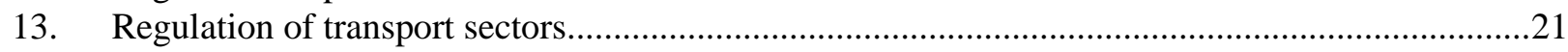

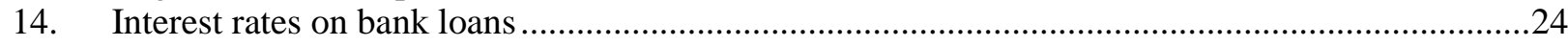

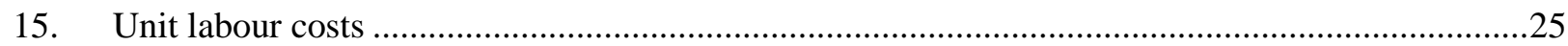

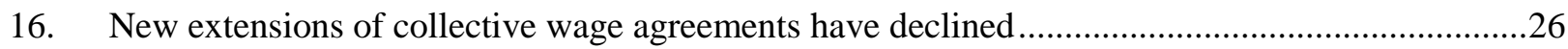

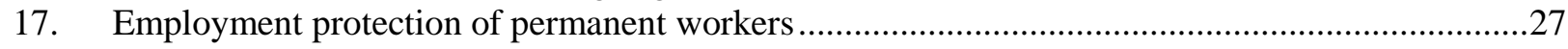

18. Upper secondary and tertiary attainment for $25-34$ year-olds.....................................................28

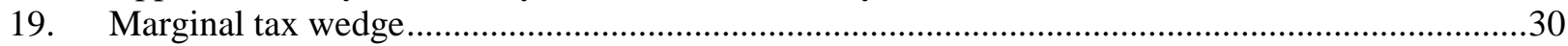

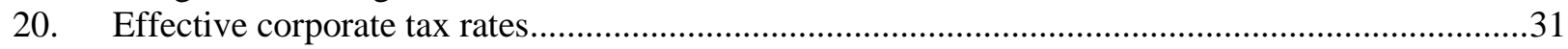

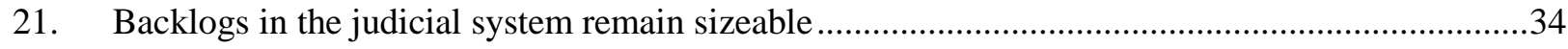

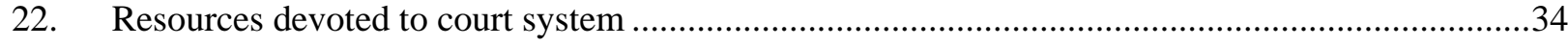

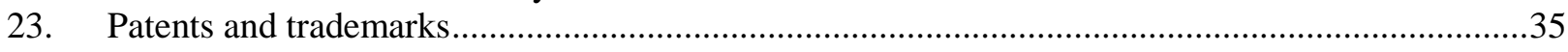

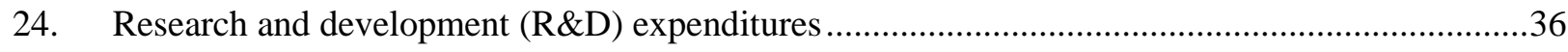

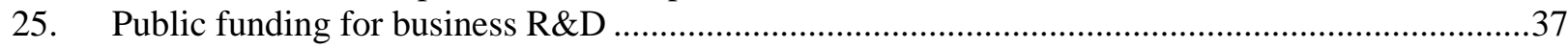

\section{Boxes}

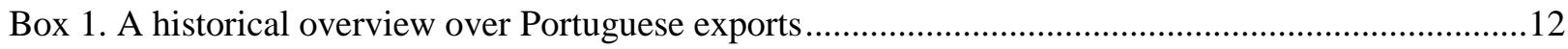

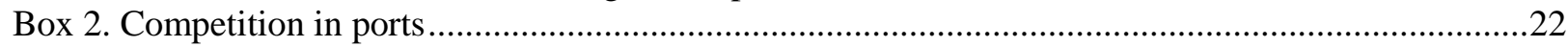


ECO/WKP(2015)75 
ECO/WKP(2015)75

\title{
BOOSTING EXPORT PERFORMANCE IN PORTUGAL
}

\author{
By Jens Arnold ${ }^{1}$
}

Between 2001 and 2010, the Portuguese economy recorded average annual GDP growth of less than one percent and a series of imbalances built up. As traditional exports contracted due to increasing competition in export markets, the non-tradable sector expanded excessively. This expansion was facilitated by surging credit flows that financed either consumption and investment projects with little productivity benefits, heavily skewed towards construction, infrastructure and other sheltered sectors (Figure 1). Funding for surge in credit came mostly from external sources, leading to high indebtedness among corporates and households, and in particular a build-up of external debt, reflected by an average current account deficit of almost 10\% of GDP between 2000 and 2009.

Figure 1. Investment allocation by sector

Percentage change between 2000 and $2009^{1}$

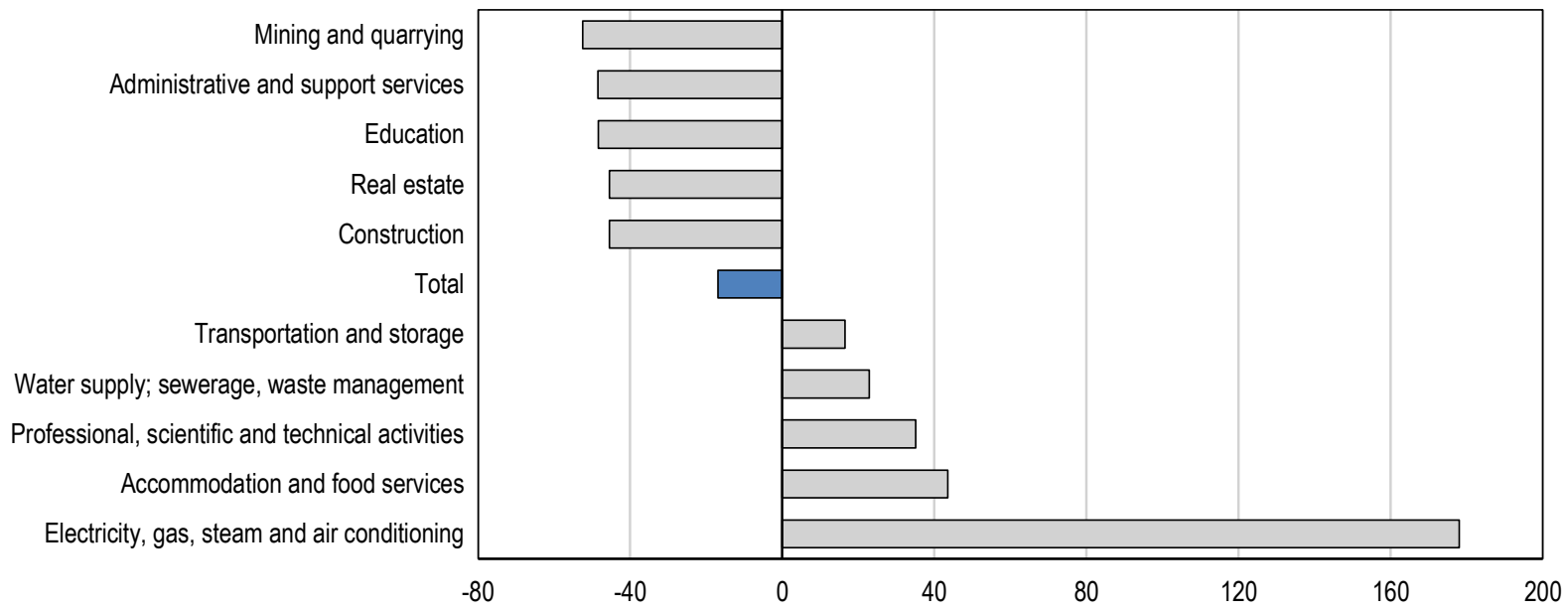

1. Investment refers to gross fixed capital formation. In real terms according to the NACE Revision 2 European Classification of Economic Activities.

Source: Eurostat (2014), National Accounts (database), April.

1. Jens Arnold is Senior Economist and Head of the Portugal/Brazil desk in the Country Studies Branch of the Economics Department of the OECD, contact email: jens.arnold@oecd.org. This paper was originally published as part of the 2014 Economic Survey of Portugal under the authority of the Economic and Development Review Committee (EDRC). It has benefited substantially from inputs and empirical work by Natália Barbosa. The authors would like to thank to Pierre Beynet, Alvaro Pereira, Robert Ford and Portuguese government officials for their valuable comments and suggestions. Special thanks are due to Gabor Fulop for statistical assistance and Sylvie Ricordeau, Dacil Kurzweg and Krystel Rakotoarisoa for technical preparation. 
During this time, the cost competitiveness of Portuguese producers deteriorated as average wages outgrew not only productivity growth at home, but also wages paid in key trading partners with much stronger productivity growth. Average unit labour costs rose until the beginning of the economic crisis relative to the euro area up until around 2010. These developments coincided with a sustained rise in unemployment (Figure 2).

Figure 2. Developments in cost competitiveness ${ }^{1}$

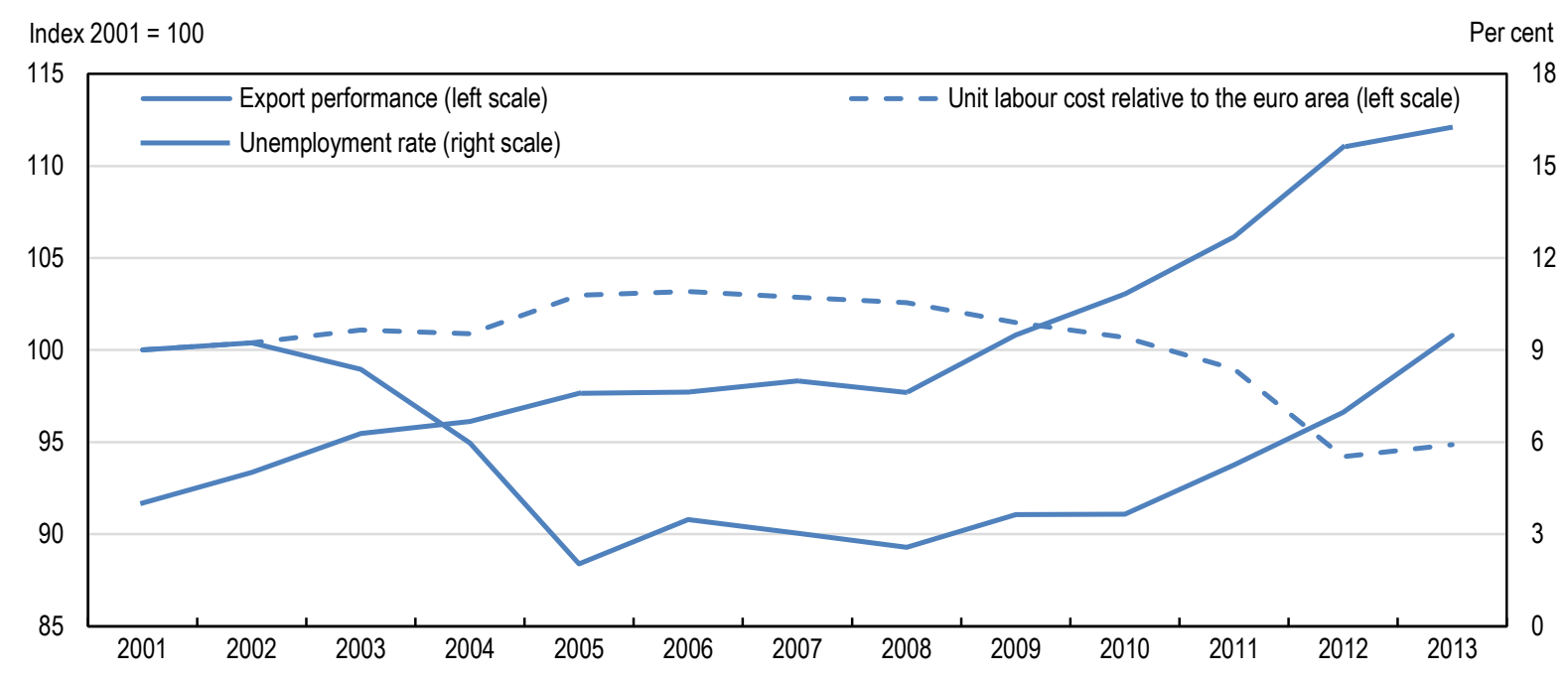

1. Export performance is the ratio between export volumes and export markets for total goods and services.

Source: Banco de Portugal (2014), "Main Indicators", BP stat, October and OECD (2014), OECD Economic Outlook: Statistics and Projections (database), October.

Signs of successful rebalancing have emerged since Portugal started an ambitious structural reform programme in 2011. Improvements in export performance (the faster growth of exports relative to the growth of export markets), particularly since 2010, have supported a turnaround of the current account to a small surplus of $0.5 \%$ of GDP in 2013 (Figure 2). This rebalancing will allow the economy to import more in the future. Against the background of almost 4 years of negative investment growth until the end 2013, and even though the allocation of investment has improved, more investment will be needed to raise growth and strengthen the efficiency of domestic production in the future, and this will lead to stronger import demand. At the same time, external debt is very high at $221 \%$ of GDP, and will need to be reduced through sustained current account surpluses. More exports are therefore the only way forward.

The current rise in exports will need to be sustained. Many Portuguese companies had to look abroad to survive, and it is yet to be seen if they return to the home market once domestic demand recovers. Thus, a recovery of domestic demand could slow export growth (Belke et al, 2013; Esteves and Rua, 2013). But in some cases, the crisis has forced companies to pay fixed costs associated to selling in foreign markets, and now that they have managed to establish themselves in these markets, they may well stay as long as their production costs remain under control.

Although exports have risen from 27\% of GDP in 2009 to 39\% of GDP in 2013, they will still need to rise further. Considering the small size of its economy, which is typically related to a stronger weight of international trade in GDP, Portugal exports less than other similar countries (Figure 3). several of which export a significantly larger share of GDP than Portugal. Therefore, Portugal's transition towards stronger exports and insertion into global value chains has still some way to go. 
Figure 3. Exports and economic size in international comparison

A. Exports and economic size

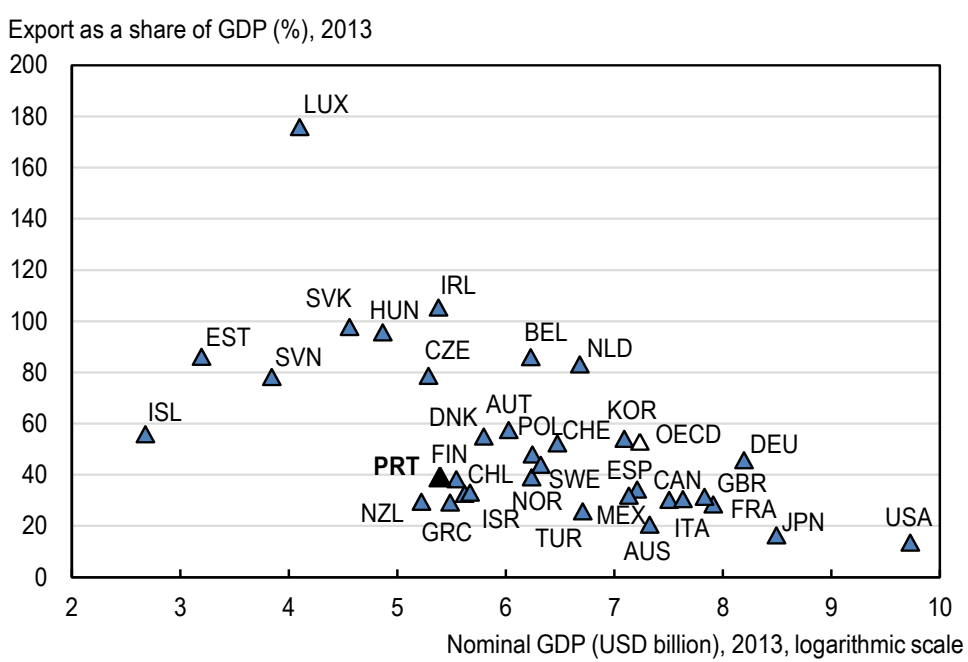

\section{B. Evolution of exports in Portugal}

$\%$ of GDP

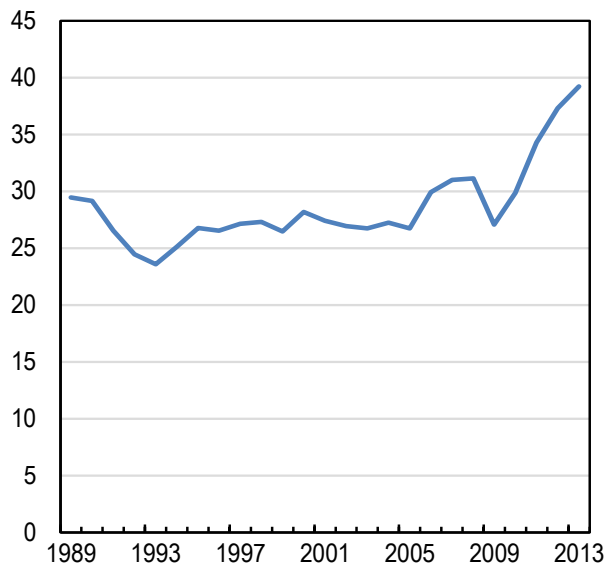

Source: OECD (2014), OECD Economic Outlook: Statistics and Projections and OECD National Accounts (databases), September.

Building on the recent progress and strengthening exports further will require both measures that strengthen the cost competitiveness of Portuguese companies and measures that ensure a sufficiently flexible industry structure in which new innovative firms can enter and thrive. In addition, enhancing innovation, the quality and the branding of exports will allow Portugal to further increase the value-added content of its exports. This paper discusses in more detail what can be done to sustain and further strengthen Portugal's recent improvement in export performance, which is key to creating urgently needed jobs and growth.

\section{Recent developments in the structure of exports}

The structure of Portuguese exports has undergone significant changes in the early 2000s (see Box 1). Nowadays, Portugal's merchandise exports, which account for around $70 \%$ of overall exports, are fairly diversified across a number of sectors. As many as 16 sectors account for more than $3 \%$ of total merchandise exports each, and only one sector, motor vehicles, accounts for more than $10 \%$ (Figure 4). Changes in the export structure have also occurred within sectors, for example in textiles and footwear, where Portugal's exports have moved into higher value-added products. 


\section{Figure 4. Portugal's merchandise exports by sectors and destinations}

Share of total merchandise exports, per cent ${ }^{1}$

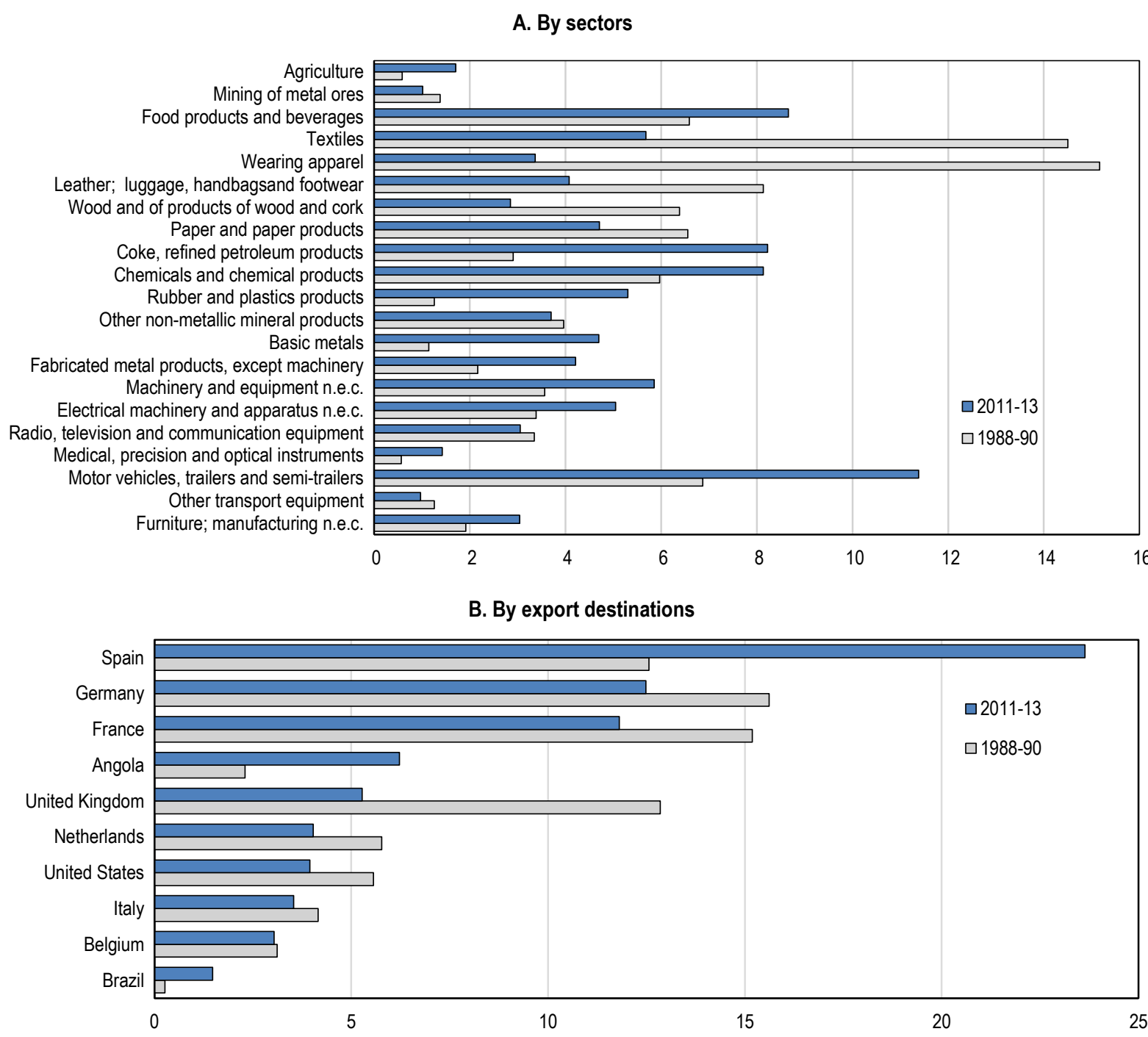

1. Average of observation periods (i.e. 1988-90 and 2011-13). N.E.C.: not elsewhere classified.

Source: UN Comtrade Database.

Several of Portugal's main export sectors are characterised by strong world trade growth, and Portugal has gained market share in a number of these over the last decade (Figure 5). This bodes well for the economy's potential to export in the future. For example, Portugal's market share has increased in chemicals, food products, agriculture and metals, all of which are sectors in which world trade growth has been above average.

The services sector has also become increasingly involved in international trade. The lion's share of this is explained by the development of the tourism sector, for which the country's climate, coastline and cultural assets provide a natural competitive advantage. But the balance of non-travel service trade turned positive in 2005 and has grown since. Exports from business services and construction services are now accounting for almost one third of the country's services exports. Evidence suggests that Lisbon has emerged as a competitive offshore option for companies from Portuguese-speaking African countries such 
as Angola and Mozambique seeking legal advice. Companies in the crisis-hit construction sector, which is generally considered non-tradable, have similarly managed to shift part of their activity to Portuguesespeaking countries in Africa. A common language has also supported rising exports of medical services to Portuguese-speaking countries in Africa.

\section{Figure 5. Portugal's export performance}

Per cent, 2003-2013

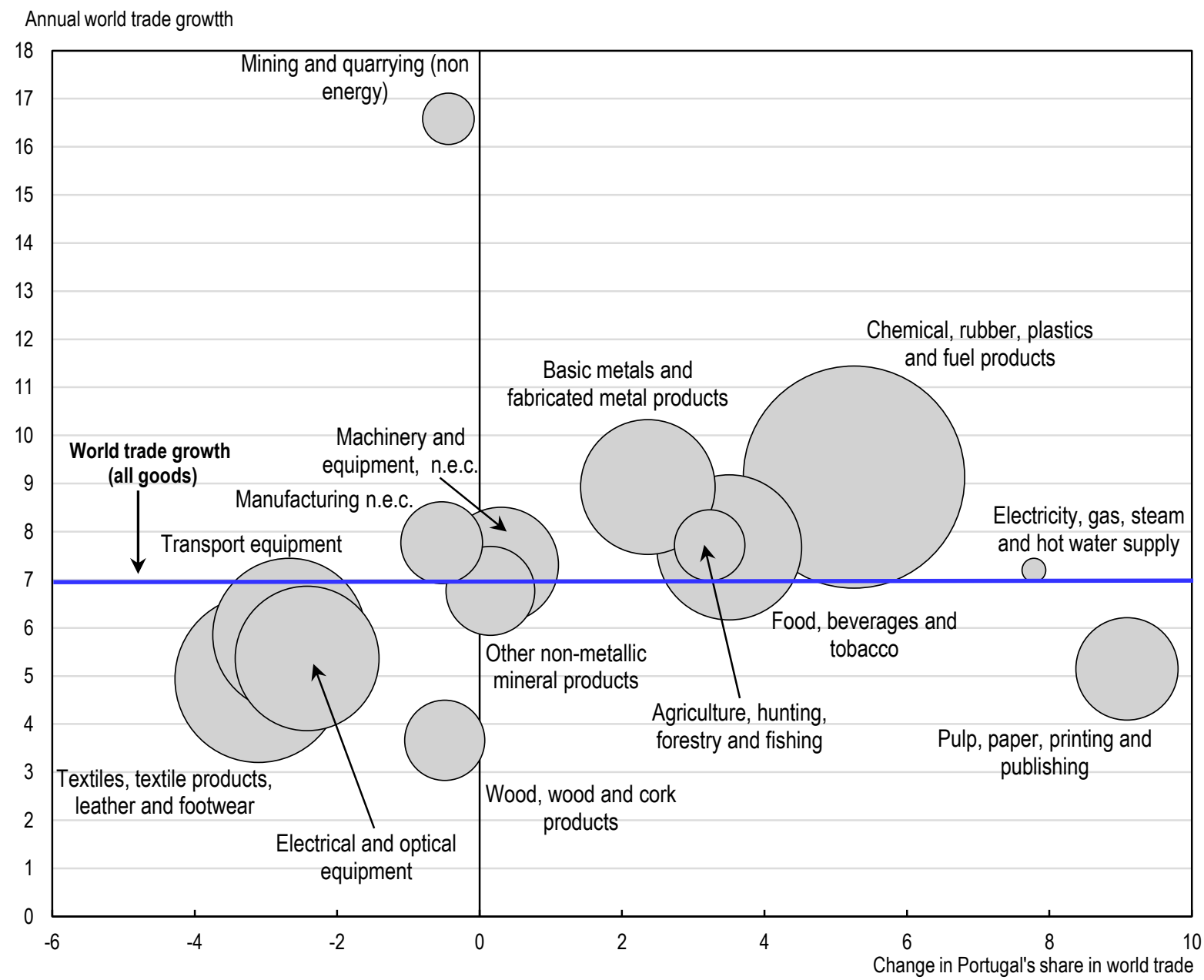

1. Industry sectors based on ISIC Rev.3 classification. The size of the bubble indicates the share of the sector in total exports in 2013.

Source: OECD (2014), International Trade by Commodity Statistics (ITCS database), July.

How to read this chart: Industries in the upper right corner are industries in which Portugal is gaining market share on world market, and where world trade growth is strong. This is the case, for example, for chemicals, rubber, plastic and fuel products, which is at the same time one of the sectors that accounts for a large share of Portuguese exports, as indicated by the size of the bubble.

Portugal has also been able to diversify its export destinations. Spain, Germany and France are the three most important export, and this was already the case in 2001. The European Union as a whole is where $71 \%$ of Portuguese merchandise exports are sold. However, non-European export destinations, in particular Angola, have become increasingly more important for Portugal. Exports to Angola have exceeded those to the United Kingdom, and non-European export destinations taken together have generated $44 \%$ of Portuguese export growth over the last decade. Africa as a whole now receives $10.4 \%$ of Portugal's merchandise exports, while Asia, North America and South America account for 5, 4 and 3\%, respectively. 
Portugal's value added content of its exports was $68 \%$, slightly below the OECD average of $71 \%$ and the EU average of $87 \%$, but higher than in a number of Central European countries. Foreign value added content is particularly high in transport equipment and electrical equipment, reflecting Portugal's strong integration into global value chains in these sectors (OECD, 2013). As in other economies, the share of intra-industry trade in Portugal's foreign trade has risen significantly, to reach around $70 \%$ in 2012 (Amador and Cabral, 2014).

\section{Box 1. A historical overview over Portuguese exports}

Since joining the European Union in 1986, wages in Portugal have traditionally been lower than in the rest of the Europe, and Portugal's competitive advantage was mostly derived from this wage differential. As a result, labourintensive low-technology sectors such as shoes and textiles featured prominently among the economy's exports, in the context of a European market that was still fairly closed vis-à-vis extra-European competition.

The wage-cost based model of specialisation was put into question by a number of events, including China's accession to the World Trade Organisation in 2001, the end of the multi-fibre agreement in 2005 and the Eastern enlargements of the EU in 2004 and 2007, all of which led to the emergence of new competitors in the niche occupied by Portugal. Significantly lower wages in some of these newly emerging competitors, particularly from Asia, required Portugal to rethink its trade specialisation strategy. Being no longer able to compete in the bottom-end price segments, Portuguese exports took a turn towards more medium-technology activities. Eastern European countries, however, soon emerged as strong competitors in this segment, with a geographic proximity to core European markets and a fairly educated labour force.

This series of events triggered profound changes in the structure of Portuguese exports. Traditional Portuguese export sectors like textiles, apparel, leather, wood and cork gave way to new export sectors such as motor vehicles, metals and metal products, plastic products, machinery and refined petroleum products. The pace of foreign direct investment (FDI) inflows also began to pick up significantly (Amador and Cabral, 2014). Broadly speaking, Portugal's export structure has managed to follow the trend of other European countries to move into more sophisticated and technology-intensive sectors. These changes have also implied significant turnover of exporting firms, giving rise to many firm closures and also a significant emergence of new exporters.

\section{A closer look at the characteristics of exporting firms}

Recent academic literature on international trade has documented how heterogeneous firms are, even within narrowly defined sectors, and highlighted how important it is to look at exporting firms for analysing international trade flows, simply because exporting firms are very different from average firms (Bernard and Jensen, 1999; Altomonte et al., 2012). While productivity varies substantially among firms engaged in similar activities, it is typically only the highest-performing firms within a sector that manage to become successful exporters. The academic literature has traced this back to the existence of fixed costs of entering foreign markets which only the most productive firms will be able to recover once they have become exporters (Melitz, 2003; Melitz and Ottaviano, 2008). In practice, such fixed costs could be related to the need to collect information about export markets, establishing commercial contacts, hiring multilingual staff or adapting products to be sold abroad.

For policies that aim to affect a country's competiveness, it may therefore be misleading to be guided exclusively by aggregate or even industry-specific averages of key variables, such as unit labour costs. In fact, the needs and challenges of exporting firms may be quite different from those of a hypothetical average firm, which is in itself a not a very useful concept given how heterogeneous firms are.

Firm-level data from the Portuguese manufacturing census Sistema Integrado de Contas (SCIE), covering over 40,000 firms over the period 2006 to 2011, confirms many of the regularities documented for other countries by the academic literature (Table 1). Around $44 \%$ of Portuguese manufacturing firms have had at least one export transaction during 2006-11, although only $10 \%$ are persistent exporters in each of these years. Exporting firms are clearly the top performers in their industry. They are on average 
about five times larger than non-exporters in terms of employment (Table 1). Both their capital stock per employee and their labour productivity are $60 \%$ higher than for non-exporters, while they enjoy a total factor productivity (TFP) premium of $13 \%$ vis-à-vis non-exporters.

Table 1. Basic characteristics of manufacturing firms by export status

Annual averages 2006-2011

\begin{tabular}{lcccccc}
\hline & $\begin{array}{c}\text { Number of } \\
\text { firms }\end{array}$ & $\begin{array}{c}\text { Number of } \\
\text { employees }\end{array}$ & $\begin{array}{c}\text { Capital } \\
\text { stock per } \\
\text { employee }\end{array}$ & $\begin{array}{c}\text { Labour }^{1} \\
\text { productivity }\end{array}$ & $\begin{array}{c}\text { TFP } \\
\text { premium } \\
(\%)\end{array}$ & $\begin{array}{c}\text { TFP growth } \\
(\%)\end{array}$ \\
\hline Non-exporters $^{3}$ & 22557 & 8.1 & 16.6 & 13.1 & -5 & -0.03 \\
Exporters $^{3}$ & 18121 & 40.6 & 27.2 & 21.0 & 8 & 0.8 \\
$\quad \begin{array}{l}\text { Only persistent } \\
\text { exporters }\end{array}$ & 4169 & 65.2 & 30.8 & 24.6 & 13 & 0.7 \\
$\quad$ Only new exporters & 1237 & 16.6 & 20.2 & 17.8 & 2 & 1.4 \\
Whole sample & 40678 & 19.1 & 21.4 & 16.3 & 0 & 0.3 \\
\hline
\end{tabular}

1. Capital stock and labour productivity are measured in multiples of EUR 1000.

2. Total factor productivity (TFP) premium measures how much higher productivity is vis-à-vis the median firm in the respective sector.

3. The differences between exporters and non-exporters are statistically significant in all cases.

Source: OECD calculations based on data from Integrated System of Business Accounts (Sistema Integrado de Contas, SCIE).

Empirical evidence that is becoming available for an increasing number of countries suggests that the direction of causality between performance and export status runs mostly in one direction: from high productivity to exporting (Arnold and Hussinger, 2005; Bernard and Jensen, 1999, 2004; Delgado et al., 2002; ISGEP, 2008; Wagner, 2012). Put differently, it is typically high-performing firms that become successful exporters, while the learning effects from exporting itself seem limited, although a few studies have found evidence supporting such learning effects (ISGEP, 2008). Evidence on new exporters in Table 1 supports this hypothesis for Portugal, as new exporters in their first or second year of export activities already display many of the characteristics that differentiate exporters from non-exporters. This finding has important policy implications. If firms need to be high-performers before they can become exporters, then the role for policy is mostly to create the right framework conditions for productivity growth, and in particular for high-productivity firms to thrive and grow, including at the expense of other less productive firms.

The firm-level data also suggests that a significant number of high-performing firms are companies that have recently entered the market, which have significantly stronger productivity growth than more mature firms, both with respect to labour productivity and TFP (Figure 6). Many new market entrants are on a steep upward trajectory during which they grow, become more productive and some of them become successful exporters (Criscuolo et al, 2014, Altomonte et al, 2012). This is part of the 'up-or-out' dynamics typical of young firms, where some successful entrants experience fast post-entry growth while others leave the market after a short time (Haltiwanger et al. 2013, Anyadike-Danes et al. 2013). About a quarter of Portuguese exports nowadays comes from firms that are less than 10 years old (Banco de Portugal, 2013). Beyond their important role for exports, young firms are also an important driver of aggregate productivity growth and job creation. Estimates suggest that about $30 \%$ of labour productivity growth in Portugal is due to net entry (Bartelsman et al., 2009). Firm-level analysis also suggest that almost half the jobs created in Portugal are in young firms (Criscuolo et al, 2014). Policies that keep entry barriers low and facilitate post-entry growth of young firms can therefore play a key role for fostering export performance, aggregate productivity growth and job creation. 
Figure 6. Young firms experience faster productivity growth

Average annual productivity growth, per cent, $2006-2011^{1}$

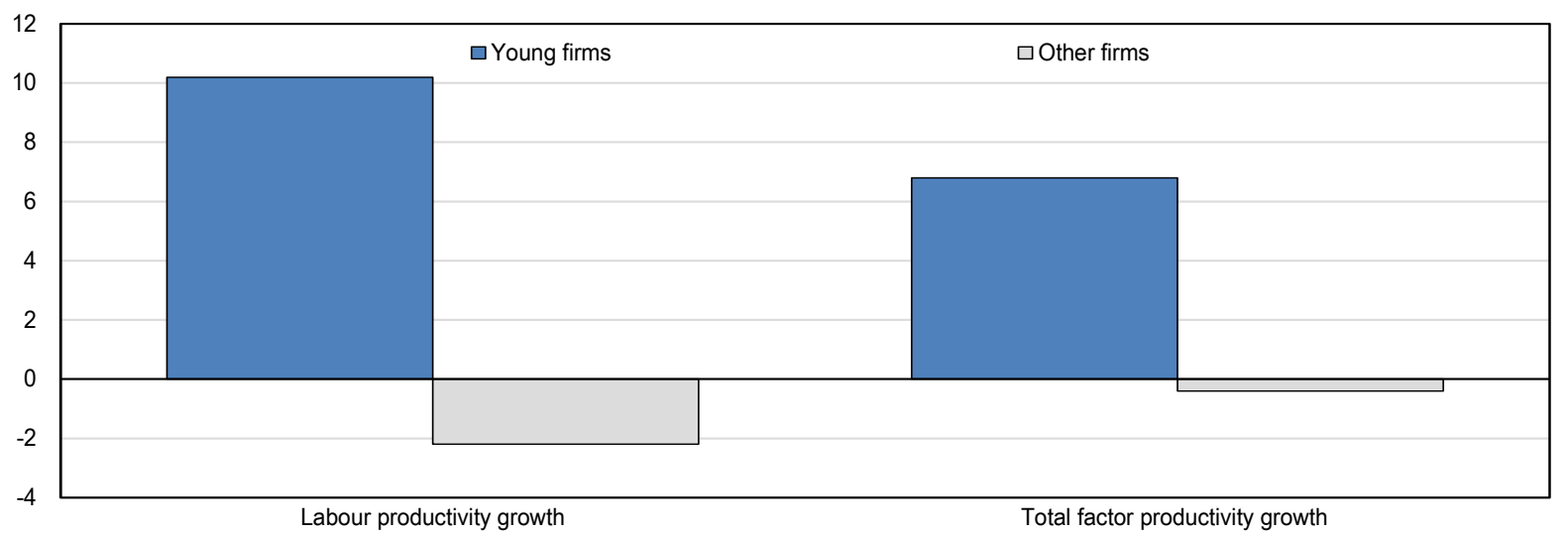

1. Young firms are defined as those aged 5 years or less.

Source: OECD calculations based on data from Integrated System of Business Accounts (Sistema Integrado de Contas, SCIE).

One salient feature of industry structures in Portugal is that small firms account for larger shares of value added than in other countries (Figure 7). This is also true for employment, with firms with less than 10 employees accounting for $84 \%$ of employment. At the other end of the size scale, only $3 \%$ of employment takes place in firms with over 50 employees. This tendency has exacerbated over the last decade, and Portugal had more small firms and fewer big ones in 2009 than it had in the 1980s, which is contrary to the trend in other countries, including countries of similar size (Braguinsky et al., 2011).

\section{Figure 7. Value added by enterprise size class}

Per cent of total value added, $2011^{1}$

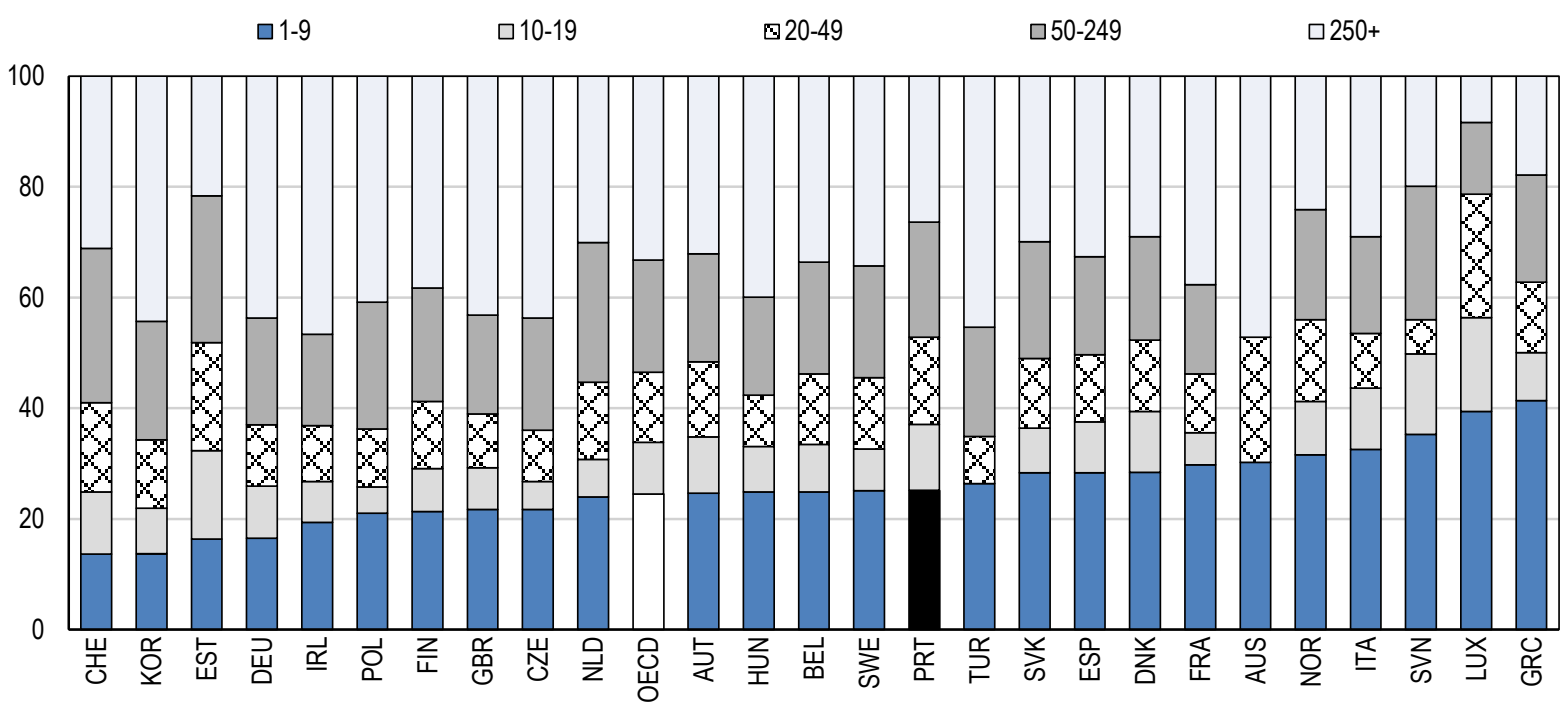

1. Data refer to value added at factor costs in EU countries and value added at basic prices for other countries. Data cover the market economy, excluding financial intermediation. For Korea in mining industry division, size class "10-19" refers to "1-19". For Australia, the size class "1-9" refers to "1-19", 20-49" refers to "20-199", "250+" refers to "200+". For Turkey the size class "1-9" refers to "1-19". 2009 for Australia, Greece and Turkey. 2010 for Denmark.

Source: OECD (2014), Entrepreneurship at a Glance 2014. 
But not all small firms in Portugal are those young and rising stars whose willingness to experiment brings new innovative ideas to the market. Only $30 \%$ of small firms are younger than 5 years old, and almost half of Portuguese small firms are more than 10 years old. In contrast to recent market entrants, these firms are generally net job destroyers and have weak productivity growth (Criscuolo et al, 2014).

In a number of policy areas, Portugal recognises explicitly the role small firms play in generating employment. Against the background of the stark differences between small firms and young firms, however, and the skewed sized distribution of Portuguese companies, the key question for policies aimed at small and medium companies should not be how to help small firms to survive as they are, but rather how to create the conditions for new firms to enter the market and for young firms to grow. In fact, some authors have linked the small average firm size in Portugal with favourable treatment for small firms in a number of regulatory areas, including employment protection legislation (Braguinsky et al., 2011; Cabral, 2007). The authorities should analyse the extent to which size-specific rules and regulations, as well as the legislation for mergers and acquisition, can be an impediment for firms to grow, and remove such impediments where they exist.

\section{Policies to improve Portugal's export performance}

The empirical evidence on exporting firms has straightforward implications. For exporters that have already successfully entered an export market, the ability to continue and export depends in part on how their costs develop relative to competitors. The cost of labour and intermediate inputs from non-tradable sectors therefore matter for these firms, but also policies that affect productivity, including the tax system, the possibility to enforce contracts through the court system, and the possibilities and incentives for firms to innovate and improve their products and processes. For potential new exporters, what matters in particular are the conditions for high-productivity firms to grow and expand, including at the expense of lower-performing incumbents. Avoiding any kind of policy settings that could put entrants at a disadvantage vis-à-vis incumbents or that could create disincentives to grow above certain thresholds is key for the emergence of new exporters.

In Portugal, the three most important input costs for firms in tradable sectors are intermediate inputs from other tradable sectors, labour costs and intermediate inputs from non-tradable sectors (Figure 8). The remainder of this paper will discuss policies that affect the competitiveness and productivity of firms, and will also flag areas where current policy settings might be putting an undue burden on potential entrants or on the growth of high-performing firms.

Figure 8. A simplified cost breakdown in tradable sectors

Per cent of costs of goods sold, mid-2000s

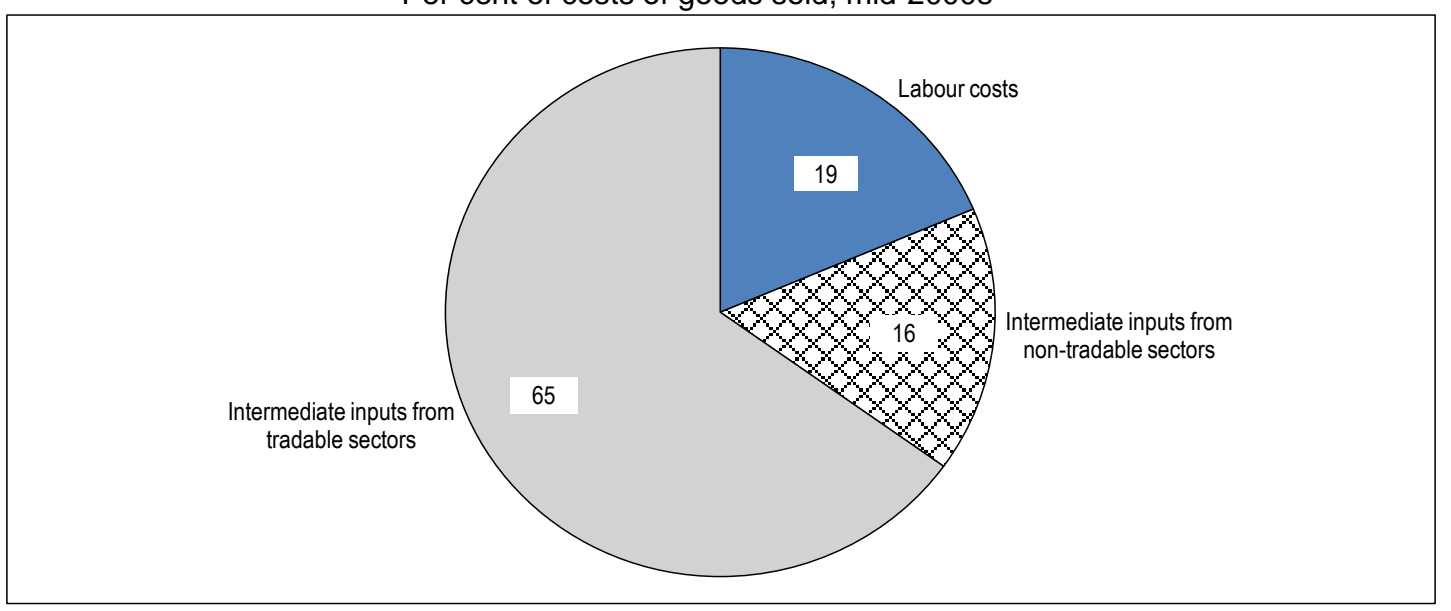

Source: OECD (2012), "STAN Input-Output: Input Output Database", STAN: OECD Structural Analysis Statistics (database), June. 


\section{Access to intermediate production inputs from non-tradable sectors}

Production inputs from non-tradable sectors account for $16 \%$ of average input costs for companies in tradable sectors, almost as much as wage costs, and are a key determinant of cost competitiveness (Figure 8). Their value added share in Portuguese exports is even higher given that inputs from other tradable sectors also contain value added from non-tradable sectors. According to OECD Trade in value added data, services, which are largely non-tradable, account for $57 \%$ of the value added of Portuguese exports (OECD-WTO, 2014). Prices in non-tradable sectors have risen significantly faster than tradable prices, even compared to other countries in the Euro area (Figure 9). This calls for further action to strengthen competition and reduce prices in non-tradable sectors, in addition to reducing labour costs.

Figure 9. Prices in non-tradable sectors have increased faster than in tradable sectors

Prices of non-tradables relative to tradables ${ }^{1}$

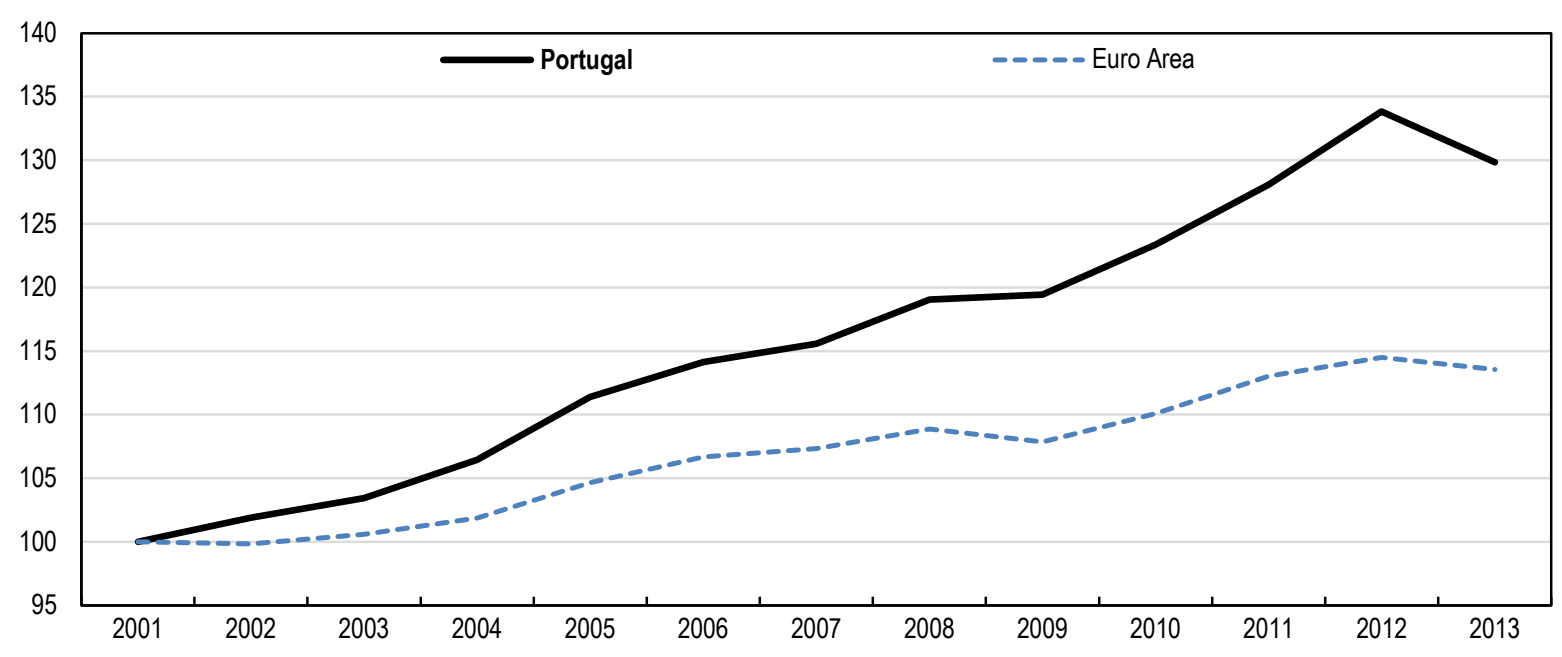

1. Ratio of harmonised index of consumer prices (HICP) $(2001=100)$ of non-tradable sectors to HICP $(2001=100)$ of tradable sectors.

Source: Eurostat (2014), Harmonised Indices of Consumer Prices (HICP) (database), July.

\section{Strengthening competition on product markets}

Product markets in Portugal have traditionally been characterised by low levels of competition in several areas, and despite substantial improvements in recent years there is much scope for further progress in reducing rents and facilitating market entry. While open borders and free international trade are generally effective in ensuring competition for tradable goods, regulation has a key role to play to ensure adequate competition in non-tradable sectors. Pro-competitive product market reforms in non-tradable sectors tend to induce lower prices, better quality and a wider array of services offered, as competition enhances the incentives for efficient production and investment. This in turn allows firms in other sectors to benefit from better inputs at lower prices, and can generate substantial downstream productivity improvements across the entire economy (Arnold et al., 2011).

OECD product market indicators measure the stringency of anti-competitive regulation across a wide range of countries. Between 2008 and 2013, the competition-friendliness of Portugal's product market regulation moved up 15 ranks among OECD countries, and it is currently ranked $11^{\text {th }}$ of 33 OECD economies for which data is available (Figure 10). Recent OECD empirical work on the basis of sectorspecific policy indicators suggest a positive and significant link between reforms that enhance competition on one hand, and multi-factor productivity and growth on the other (Bourlès et al, 2013). The empirical relationships estimated in this work can be used for simulation exercises, which allow an initial 
approximation of the quantitative benefits of further product market reforms. By focusing on sourcing relationships between different sectors of an economy, these estimates are able to capture the economywide effects of reform actions in individual sectors.

Figure 10. Aggregate product market regulation indicator Index scale of 0-6 from least to most restrictive ${ }^{1}$

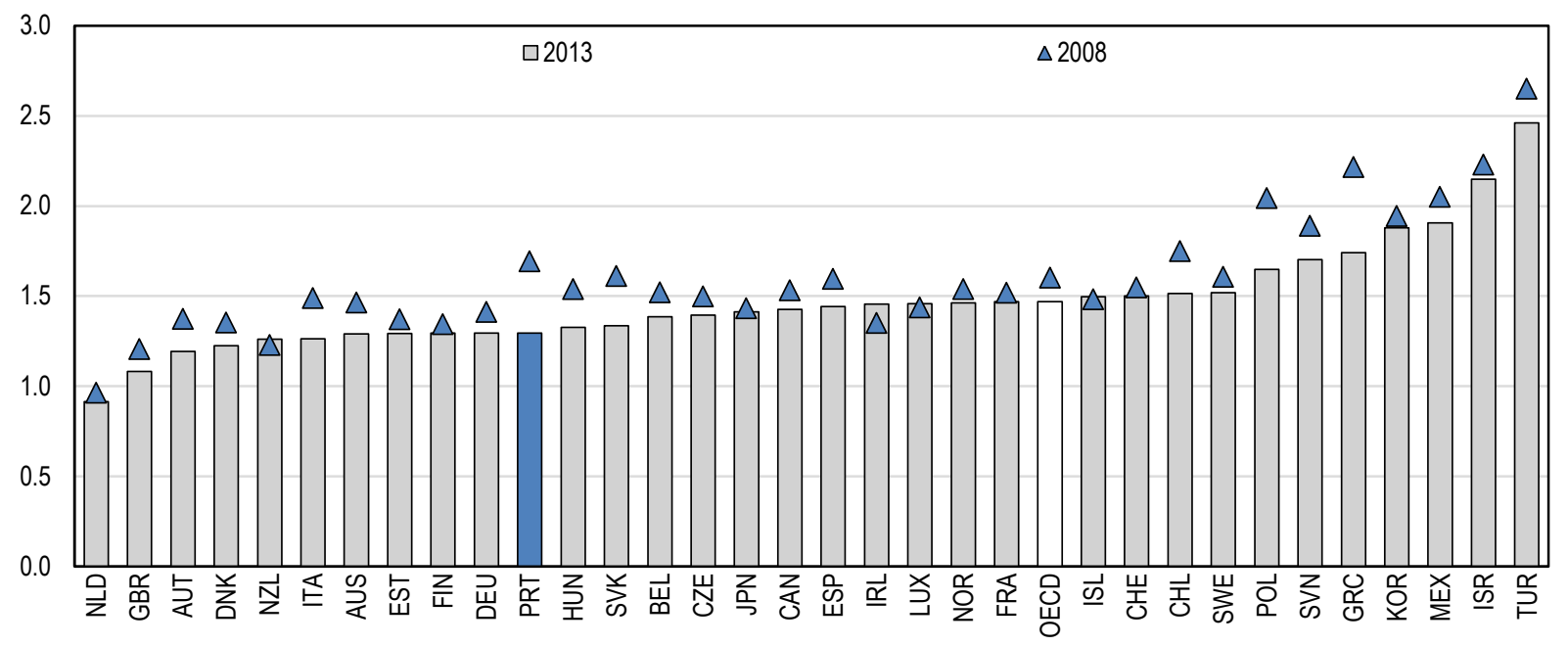

1. The OECD aggregate is an average of the data shown.

Source: OECD (2013), OECD Product Market Regulation Database.

The results of such simulations suggest that the product market reforms undertaken since end 2008 including improvements in the electricity, gas and retail trade sectors - will raise the level of GDP by $3 \%$ by the year 2020 (Figure 11). But much more could be done. A reform scenario in which Portugal would further reduce regulatory barriers to competition by $20 \%$ in each sector - corresponding roughly to the magnitude of changes observed over the past ten years in those OECD countries that have implemented product market reforms - would raise GDP by an additional $2 \%$ by 2020 . A more ambitious scenario in which Portugal would align its regulation to best practice among all OECD countries in the various areas and sectors of product market regulations would yield an increase in the level of productivity and GDP of $5 \frac{1}{2}$ percent by 2020, and even more over the longer term (Figure 11). In this scenario, the growth effects of product market reforms are equivalent to an increase in GDP growth by around 0.8 percentage points each year between now and 2020, or an annual increase in nominal GDP of EUR 1.3 billion, measured in 2014 Euros. The overall effect of product market reforms undertaken since end-2008 combined with the additional reforms needed to move to OECD best practice would deliver a total gain of $8.5 \%$ in the level of productivity and GDP. While there are obvious uncertainties surrounding such empirical exercises, they clearly suggest that further reforms of product market regulations hold great potential to raise growth and living standards. 
Figure 11. Expected gains from product market reforms

Impact on the level of productivity and potential GDP by 2020, per cent

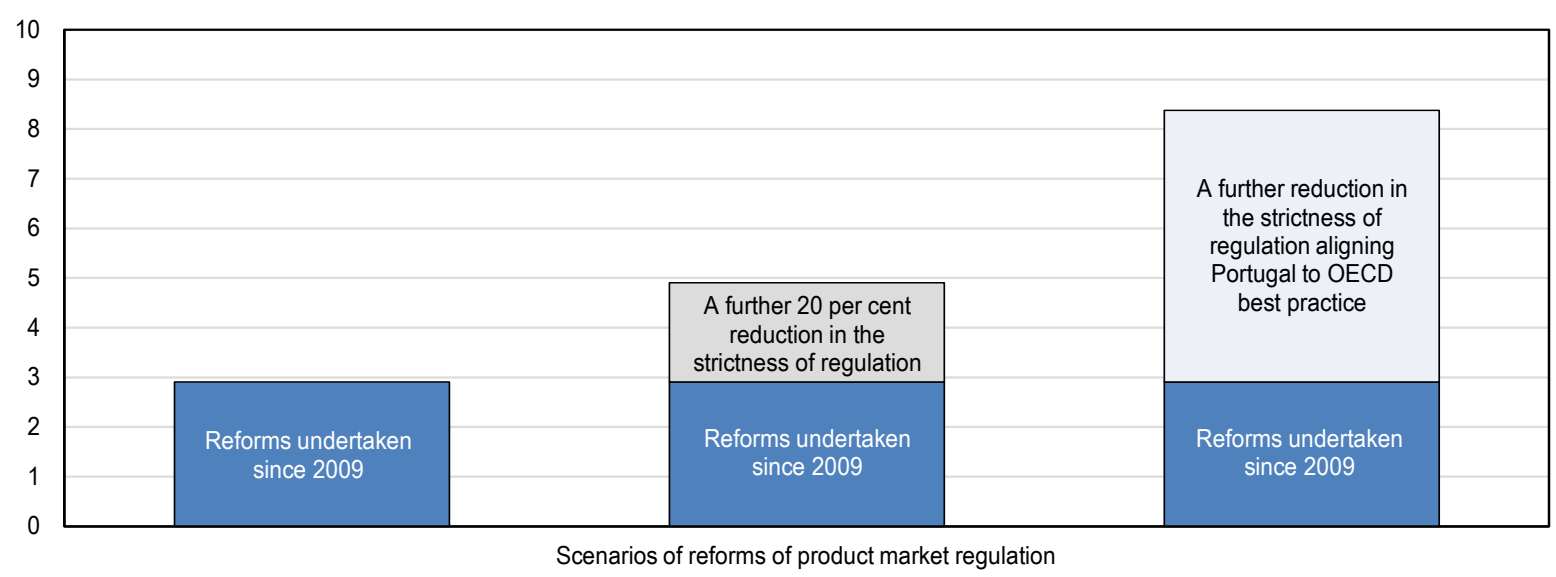

Source: OECD estimates.

\section{Energy sector}

More specific indicators for individual sectors suggest that substantial progress has been made in network sectors, where Portugal has become the OECD country with the second most competition-friendly regulation. However, despite this progress in legislation, several network industries are still facing significant challenges with respect to competition, and rules are not the only factor that affects the de facto strength of competition in a given sector. For example, the energy sector is still characterised by an insufficient use of market mechanisms, highly concentrated retail markets and high prices in international comparison.

Despite the ongoing liberalisation of the electricity sector, the largest incumbent operator retains a strong position in retail markets. Generation of electricity is formally open to competition, but unlike potential new entrants, incumbent operators benefit from legacy remuneration schemes such as power purchase arrangements, guaranteed compensation mechanisms and high feed-in-tariffs that continue to provide sizeable rents to incumbent electricity generators. The surge in renewable energy sources has increased electricity costs through price guarantees for electricity from both renewable and non-renewable sources. Some non-renewable electricity generation capacity is rewarded by these price guarantees to stand ready when the more intermittent renewable energy is insufficient to meet demand. In fact, over $90 \%$ of electricity production is sold at guaranteed prices, which leaves little room for the fluctuating "market price" at which the remainder of the electricity is sold and reduces the scope for effective competition.

In 2007, existing power purchasing agreements with fixed prices (CAE) for 26 hydroelectric and thermal power plants were replaced by a mechanism that would top up market prices instead (CMEC). These contracts, all of which with the former incumbent operator, remunerate electricity production and backup capacity according to a complex formula, resulting in acquisition costs that were more than $30 \%$ above market prices in 2013. The top-up mechanism basically eliminates all risk related to market volatility for the incumbent operator, and accounted for around a third of its profit before taxes in 2012, according to the competition authority. The number of power plants under the CMEC regime will gradually decrease as older contracts retire, but this will not be until 2027 for the last of them. After a renegotiation, the authorities and the incumbent operator agreed on a reduction in CMEC payments between 2013 and 2027, but the total net present value of this reduction amounts only around a quarter of the CMEC payments made in the year 2012. 
For wind energy producers with feed-in-tariff regimes dating from before 2005, a revised feed-intariff scheme was negotiated in March 2013, whose main consideration was to balance the need for cost reductions with investor certainty. Producers could voluntarily opt into the new scheme and the overwhelming majority of the power plants concerned have done so. As a result, they benefit from guaranteed prices for an additional 5 or 7 years beyond the 15 year-validity of their original remuneration scheme, after which they would otherwise be remunerated at market prices. In return for this extension, producers that opted into the new scheme have to pay a contribution to the maintenance of the national electric system until 2020, and accept lower feed-in-tariffs, which are based on the daily average wholesale market price subject to a floor and cap. However, the definition of the floor significantly reduces the link to market prices unless the latter rise significantly in the future, because the floor is above the average market price prevalent in 2013. Cost reductions have been more successful for the scheme supporting micro and mini production of renewable electricity, which saw a reduction in feed-in tariffs by $30 \%$ in 2013.

Going forward, the current schedule for phasing out legacy agreements should be accelerated, including by exploring the scope for further renegotiations with incumbent companies. Over the next 8 years, electricity prices are set to rise by an additional $1.5 \%$ to $2 \%$ in real terms as electricity prices have been kept below production costs for many years, which has led to the accumulation of a debt of some EUR 4 billion (2.5\% of GDP). It is to be gradually wound down by 2020 . With electricity prices already high, particularly for electricity-intensive industrial consumers, this will have significant costs in terms of competitiveness. For an average of consumption bands between $20 \mathrm{MWH}$ and $150000 \mathrm{MWH}$, for example, electricity prices in Portugal are already 9\% above the EURO-area average (Eurostat, 2014). Some recent measures, including an extraordinary contribution for the energy sector in October 2013, and subjecting energy assets to a $0.85 \%$ tax in 2014 can contribute towards achieving these goals as long as they are not passed on to end-users and do not stand in the way of further rent-reducing measures, particularly since the expected revenues from these measures are fairly low.

Efficiency gains in the electricity sector could also help to reduce prices, and could be achieved by improving international interconnection capacity. While the electricity markets of Portugal and Spain are increasingly well connected in a common Iberian electricity market (MIBEL), better connections from Spain to France, and onward to other European countries, could allow more competition and facilitate grid management. In the current circumstances, there are concerns that Iberian electricity consumers might be unable to benefit from the advantages of a fully-integrated European electricity market. This situation, however, cannot be solved without international collaboration from Portugal's European partners.

In the retail market for natural gas, the incumbent operator, however, continues to provide more than half of the sales volumes and owns exclusive contract rights to the supply of wholesale pipeline gas from Algeria. The regulator should further require GALP to auction Algerian pipeline gas to other firms with no pre-set minimum price.

Stronger competition could be facilitated by intensifying market integration across borders. The common Iberian gas market (MIBGAS) is still hampered by lack of interconnection capacity between Portugal and Spain, and by cross-border transfer charges imposed by Spain. The Portuguese energy regulator, in tandem with the Spanish energy regulator, should fully implement the inter-governmental agreement to reduce the cross-border transmission charges between Portugal and Spain to zero. However, despite scope for better integration between the two Iberian countries, most potential benefits could once again accrue from better onward connections to other European markets. Portugal has been working to diversify its sources of natural gas through a major expansion of liquefied natural gas capacity at its Sines port, which allows larger vessels to call that port, and capacity increases of underground storage caverns at Pombal. This has the potential to lower import prices, and with better onward connections to the rest of Europe, the Iberian peninsula could become an additional alternative source of gas supply for several European countries. 


\section{Professional services}

Regulation in professional services such as accounting, legal, architecture or engineering services is more restrictive than the OECD average (Figure 12). Regulatory provisions that can stifle competition include the strong role of professional associations for regulating entry, a setting that typically favours current insiders over potential entrants. In addition, exclusive rights that reserve certain tasks only to members of a particular profession as well as regulations of prices and fees or the form of business further restrict competitive pressures. A new framework law was approved in 2013 that reforms regulations in 18 professional services, but implementation lags behind. For example, the bylaws of several professional associations have yet to be aligned with the new framework law.

\section{Figure 12. Regulation of professional services}

Product market regulation indicator, index scale of 0-6 from least to most restrictive, $2013^{1}$

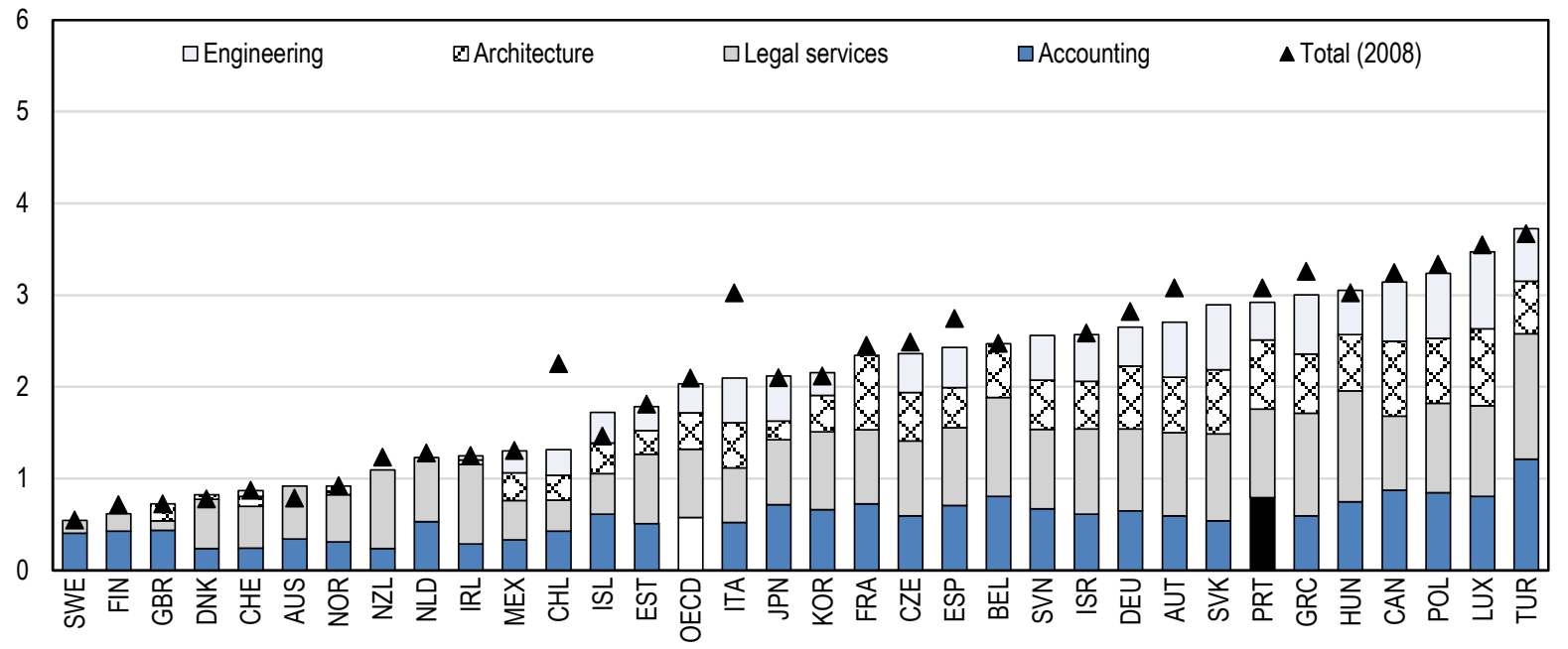

1. The OECD aggregate is an average of the data shown.

Source: OECD (2013), OECD Product Market Regulation Database.

Cross-border competition through either arms-length transactions or the establishment of foreign professionals can also play an important role for competition in professional services. The OECD Services Trade Restrictiveness Indicators (STRI) take stock of regulations that hinder cross-border trade in services industries. These indicators show that Portugal has more restrictive regulations in accounting services, architecture, engineering and legal services than the average OECD country. For example, in accounting services, Portuguese or EU nationality is required to obtain a license to practice and there are restrictions on owning shares in accounting firms, combined with specific nationality and licensing requirements for board members and managers of accounting firms. The investment regime is similar for legal services. However, there are no nationality requirements for lawyers and foreign professionals can be qualified to practice after recognition has been granted. Additional limitations affecting both professions in Portugal include restrictions on firm names and on advertising.

Transport services and ports

In transport services, the degree of competition is less than in other OECD countries, partly due to more anti-competitive regulations (Figure 13). Recently, steps have been taken to prepare to transition to competition, including the establishment of a new independent regulatory agency for transport in the context of the new regulatory framework law in 2014. In rail services, more than a decade after the formal 
separation of network and train operations, ownership of merchandise terminals will be handed over from the state-owned cargo rail company CP Carga, for which privatisation plans exist, to the network operating company Refer this year. This step is a precondition for competition in cargo rail services, as it will allow potential competitors access to these terminals and reduce entry costs.

Figure 13. Regulation of transport sectors

Product market regulation indicator, index scale of 0-6 from least to most restrictive, $2013^{1}$

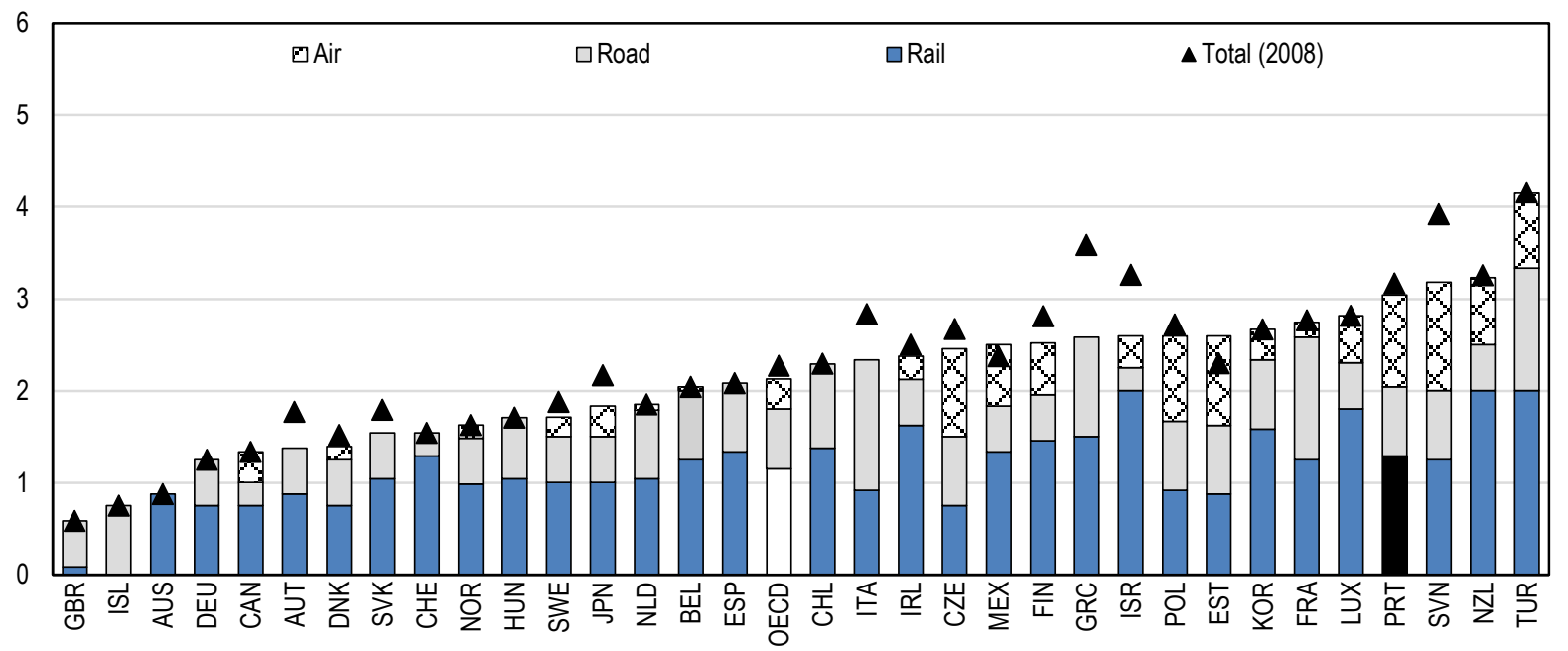

1. The OECD aggregate is an average of the data shown.

Source: OECD (2013), OECD Product Market Regulation Database.

Obstacles to competition also remain in air transport services. After a failed privatisation attempt, Portugal maintains public control in the national air carrier TAP, which may weaken performance incentives and limits the ownership of its equity shares. EU regulation on air services restricts non-EU equity participation in air services to less than $50 \%$, which has led one unsuccessful bidder in an earlier bidding round to adopt EU citizenship. Airport take-off and landing slots are allocated based on historical rights and the commercial exchange of slots is not allowed. Furthermore, air carrier alliances, particularly code-sharing arrangements, are exempt from competition rules.

A sector of particular importance for Portugal's competitiveness is ports. The country relies heavily on seaborne trade, with about two thirds of the imported and half of the exported goods being transported by sea (EC, 2014). A well-functioning and cost-effective port sector is also crucial for competitiveness, as port-related costs can often exceed $30 \%$ of total good transport costs (EC, 2013).

Recognising long-standing inefficiencies, the authorities have undertaken a series of reforms that aim to reduce port user costs. A particularly rigid Port Works Law has been made more flexible, and the scope of its application has been limited to core port tasks such as cargo handling, while related activities are now governed by the regular labour code. This has reduced port labour costs and enhanced the flexibility of port labour supply. However, the cost savings resulting from the new Port Works Law have not yet been fully passed on to ports users. The authorities are planning renegotiations of existing port concession contracts to achieve lower user costs. Administrative procedures in ports have been simplified through the introduction of single windows and the regulatory framework has been updated. In addition, the elimination of a tax on cargo handling, TUP Carga, which used to generate annual revenues on the order of EUR 25 million, has directly reduced port user costs. 
More competition in the ports sector could be a powerful tool to ensure that cost savings for terminal operators, such as those resulting from the new Port Works Law, are passed on to downstream users. There are a number of ways in which other countries have successfully introduced competition in the ports sector (Box 2). While the scope for competition between different ports may be limited in a small country, there is a large potential gain from increasing intra-port competition in Portuguese ports, either through competition between independent terminals or between different services providers. More competition would likely lead to further reductions in costs and rents, resulting in lower user charges, and there is evidence of substantial scope for this. Ports services providers have in the past been found to increase their prices to 21 times fold, and have been convicted twice by the Portuguese Competition Agency for cartel formation (OECD, 2011).

\section{Box 2. Competition in ports}

A port's efficiency is associated with its ownership structure, which determines the balance between private sector efficiency and public control. Although some ports are entirely owned and operated by public port authorities (the "service port model"), most major ports have adopted a mixture of public and private ownership, under which, frequently, public port authorities provide the infrastructure and private firms provide the superstructure and employ labour (ICA, 2013). This structure, known as the "landlord model" and adopted in Portugal, allows substantial private participation to enhance efficiency and reduces public investment requirements. Nonetheless, maximising the potential efficiency gains from private participation is far from trivial and depends on careful policy design.

The efficiency gains from private participation will be greater where elements of competition can be introduced so as to provide the right incentives for keeping costs and rents low. However, the sector is characterised by significant economies of scale and the high entry costs of investing into the terminal superstructure, which have in the past supported the notion of ports being basically natural monopolies. Even though in some cases of smaller ports, this may be true and a regulated monopoly may turn out to be the most efficient operating model, in most cases there will be some scope for reaping the benefits of competition.

Concession contracts for terminal operation allocated through regular auctions can create competition for the market rather than competition in the market, and the challenge for the concession design is to strike the right balance between shorter concessions, which imply more regular competition, and longer concessions, which provide a higher return on and hence stronger incentives for investment. Concession contracts should clearly specify all relevant parameters, including the trajectory of regulated user charges, the investment requirements, the maintenance of assets, the allocation of different risks and the level of services to be provided.

Competition in the market is also possible in the ports sector, either between different ports or between different terminals in the same port. Intra-port competition has proven to be a particularly promising model for improving market structures, especially in cargo handling services, which account for 70 to $90 \%$ of port charges (ICA, 2013). Opening stevedoring operations to competition in Guayaquil, Ecuador led, for instance, to a $60 \%$ reduction in port charges and increased productivity by $55 \%$, while the opening of ports terminals to competition reduced port charges by $80 \%$ in Buenos Aires, Argentina (Guasch, 1996). However, even in settings with more than one market player, the long timehorizon of the infrastructure investment, the small number of competitors and the repeated market interaction between players create favourable conditions for collusion, and requires strong vigilance from competition authorities. In 2007, for example, the Portuguese competition authority fined three tug services suppliers for price-fixing and allocating customers among them (OECD, 2011).

Inter-port competition is often limited by geography. Since on-land transport is more expensive than sea-freight (ICA, 2013), ports with better connections to the final on-land destination enjoy significant competitive advantages. Competition may also be limited if ports are highly specialised, or by technical constraints such as insufficient water depth for large vessels. Contractual clauses that grant exclusivity rights to certain providers of downstream services, which may be vertically integrated with port operators, can also act as an impediment to competition. For example, the German port of Puttgarden denied access to Norwegian ferry companies to reduce competition for the port's downstream shipping business until competition authorities put an end to this practice (Bundeskartellamt, 2010).

Where entry costs are prohibitively high but competition would be desirable, one possible way to lower market power is for the public sector to acquire both the infrastructure and superstructure and lease it to private firms. This model of port operation is often called the "Tool port". 
Much of the future efficiency of Portuguese ports will depend on the continuation of reforms. General guidelines for restructuring the legal framework governing ports have been set. These include the introduction of a simpler and more transparent user fee structure, the renegotiation of existing concession contracts and guidelines for future concessions. Long-standing problems to be tackled include weak port governance, including the absence of service level agreements attached to concession contracts, and a lack of hinterland railroad connections. Over $40 \%$ of the expenditures related to the government's new infrastructure investment priorities until 2020 will be dedicated to the latter issue, which will improve Portugal's connections with Spain and other European markets (SSPM, 2014). Beyond the downstream effects on the competitiveness of other sectors, the ports sector could also open new growth opportunities. Located at the intersection of major shipping routes from Europe to Asia and America, Portuguese ports could attract more trans-shipment business, i.e. the transfer of merchandise from very large vessels running intercontinental routes onto smaller ones serving different regional destinations. This could lead to stronger export performance in transport services.

\section{Competition policy}

In recent years, Portugal's competition law has been modernised and brought into line with European guidelines. However, effective enforcement of competition policy is equally essential as legal reform to foster a pro-competition environment. The Portuguese Competition Authority, whose new bylaws have recently been approved in the context of a new Competition Law approved in 2012, lacks adequate resources to be able to act effectively against vested business interests. In particular, the unit in charge of competition assessment needs to be better supported so that it plays a central role in sector reviews of existing regulation, particularly related to barriers to entry and command and control regulation.

The OECD has developed a Competition Assessment Toolkit to help identify new and existing regulations that pose unnecessary barriers to competition and to help lift the barriers identified. Sector-specific competition assessments of regulations have recently been carried out in Greece, for example, with a review of four sectors (tourism, retailing, food processing and building materials) that together account for $21 \%$ of GDP. In total, the assessment resulted in 329 recommendations for change with a total economic benefit estimated at $2.5 \%$ of Greece's GDP. Building on the expertise of the competition authority, such a sector-based competition assessment review could help to identify changes needed to regulations that restrict competition and provide central government support for implementation of recommended reforms.

\section{Improving access to finance for Portuguese firms}

Bank credit to firms is still contracting, in particular loans by domestic banks to large companies, although financing from foreign sources has increased. The conctraction of bank credit may reflect declining credit supply or demand. Interest rates on bank loans are high in international comparison, which may reflect banks'credit risk assessment and the fact that banks are still facing financing constraints and high funding costs (Figure 14). In the Euro area, the financing costs of Portuguese corporates are surpassed only by Greece. Even for those firms for which new credit is available, which tend to be concentrated in export sectors, these high financing costs put Portuguese companies at a direct disadvantage vis-à-vis foreign competitors. Non-financial companies still bear a debt burden of $156 \%$ of GDP (based on the OECD debt definition), which is the third highest corporate debt level in the OECD, after Ireland, Iceland and Luxembourg. These numbers suggest that part of the credit contraction is a natural consequence of the deleveraging needs of Portuguese companies, which may imply a stronger need to finance investment from retained earnings than in the past. 
Figure 14. Interest rates on bank loans

Interest rate on loans to non-financial corporations, per cent per annum ${ }^{1}$

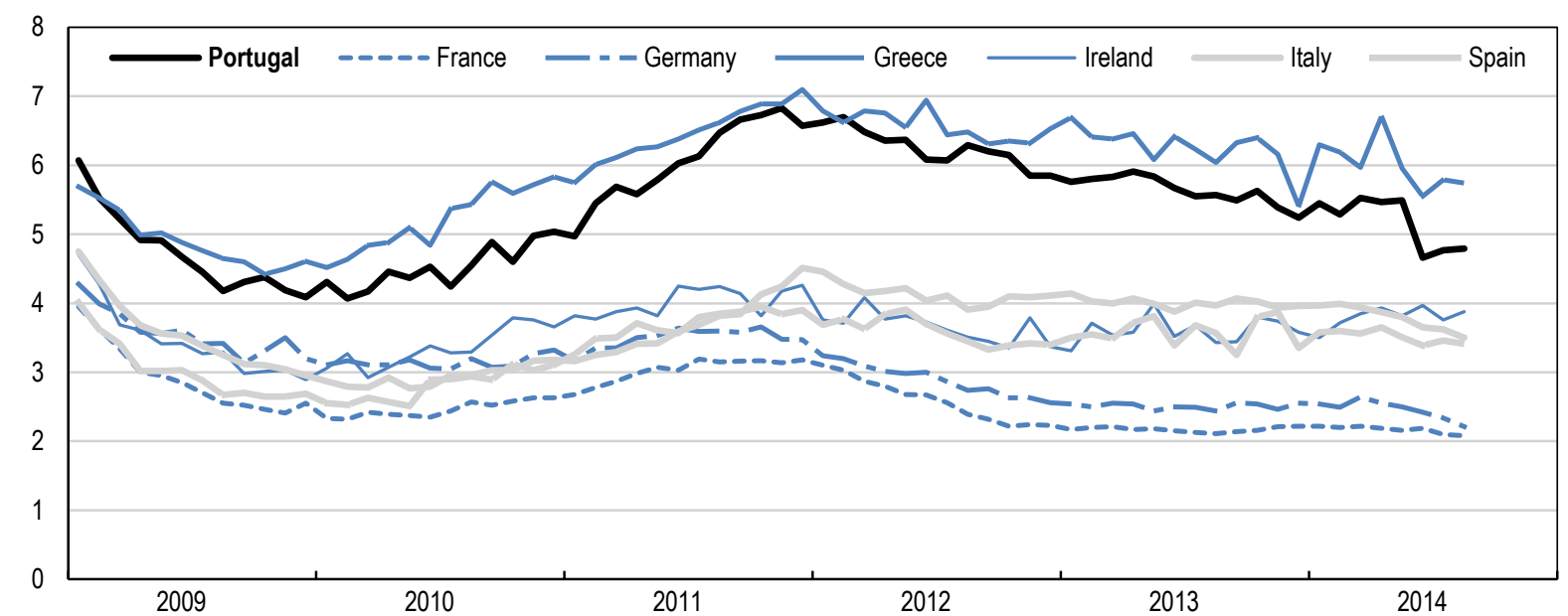

1. Figures refer to total loans (defined for cost of borrowing purposes) to non-financial corporations. The total for maturity is calculated by weighting the volumes with a moving average.

Source: ECB (2014), "MFI Interest Rates", Statistical Data Warehouse, European Central Bank, October.

Small and medium companies face particularly high interest rates, while Portugal's largest companies can access credit markets abroad at significantly lower rates. Recent government initiatives to increase the lending resources available for small and medium-sized enterprise (SME) loans, including through the use of EU structural funds and the consolidation of existing SME financial support programmes into a new Development Financial Institution which will be operational before the end of 2014 may alleviate the difficulties of accessing finance for these firms. A new SME credit programme worth EUR 2 billion has been established in March 2013, with part of the funds earmarked for promoting export activities of SMEs. However, in light of the stark differences between young start-up firms that are initially small and SMEs more generally, there is a risk that specific SME credit programmes do not reach those firm that could contribute most to aggregate productivity and to export performance. A clearer focus on start-up financing and supporting young firms rather than small and mature firms would likely be more efficient for enhancing Portugal's export performance.

The need to focus on young firm also strengthens the case for providing alternative models to debtfinancing, in particular through more availability of venture capital and other forms of equity-based startup financing. Venture capital can be an important source of funding, especially for young technologybased firms, for which obtaining bank credit has traditionally been difficult due to a high perceived riskiness and a lack of collateral. Given that venture capital markets are significantly more developed in other countries both in terms of the amounts invested and the amount per deal, in particular in the United States, there appears to be scope for strengthening this financing model in Portugal. The government has supported venture capital through a public outfit called "Portugal Ventures" in the past. The authorities should explore ways to strengthen the availability of venture capital further, including through the planned public SME financing institution. Exits from venture capital and other private equity investments, through trade sales (mergers and acquisitions) or initial public offerings (IPOs) on stock markets, provide an opportunity for investors to realise returns from their investment and potentially free up funding for further investment in innovative young firms. 


\section{Access to labour inputs}

Labour costs are an important ingredient of cost competitiveness, accounting directly for $19 \%$ of costs of Portuguese companies in the tradable sector. Besides direct labour inputs, labour costs also have an additional indirect influence on competitiveness through labour services embedded in intermediate inputs from other sectors. But it is not only the cost of labour that matters for firms, but also the skill set of the workforce. Skills are a crucial determinant of the ability of firms to move up the value chain into higherquality products with better profit margins.

After years in which unit labour costs rose faster in Portugal than in its main trading partners, they have recently declined, particularly in the manufacturing sector (Figure 15). Comprehensive labour market reforms have contributed to this decline. Overtime pay was cut in half and working time was increased through a reduction of annual leave entitlements from 25 days to 22 days and the abolition of four national public holidays. Firms have gained more flexibility in work time arrangements, following the introduction of a bank of hours that allow a maximum of 150 hours per year to be used in agreement between the employee and the employer. Four public holidays and employees' entitlement to three additional vacation days per year based on seniority were eliminated.

Figure 15. Unit labour costs

Index $2008=100$

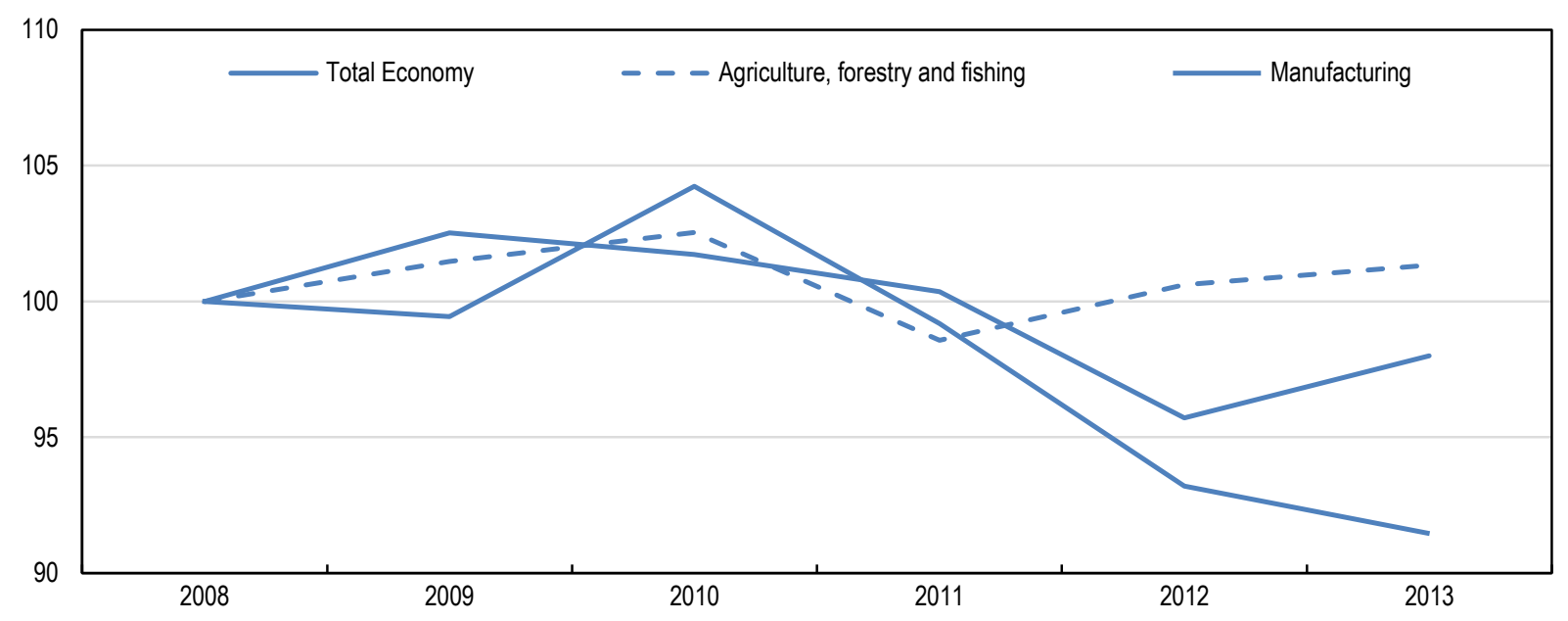

Source: Gabinete de Planeamento, Estratégia, Avaliação e Relações Internacionais do Ministério das Finanças (GPEARI).

\section{Wage-setting mechanisms}

Collective wage bargaining has typically been at the sector level between the trade unions and employers' associations. The resulting collective agreements are used to determine wage floors that became binding for the entire industry through administrative extension. This mechanism limits the scope for wage agreements to adapt to the situation of specific firms and gives extra clout to those sitting at the negotiating table. By effectively stifling firm-level bargaining, this mechanism discourages the entry of new firms and competition in product markets, as one way new firms can enter the market is by paying lower wages than incumbents for some time.

New cases of administrative extensions were effectively suspended in May 2011, and a condition that negotiating employers' associations represent at least $50 \%$ of the workers in the relevant economic sector has prevented their re-emergence since then. This additional requirement effectively caused a freeze of 
administrative extensions, and implied a sharp drop on the number of workers covered by new extensions (Figure 16). The re-emergence of administrative extensions is planned, including by introducing alternative criteria that would allow extensions when the employer side includes $30 \%$ of small and medium enterprises; this would be an easy target to meet and would probably make administrative extensions the norm again in most sectors. However, such a change would clearly be a step backwards. Instead, more should be done to promote collective bargaining at the firm level, including by abolishing administrative extension altogether. Recent plans to shorten the survival of any expired collective bargaining agreement in the absence of a new agreement from 5 to 2 years would be a step in the right direction.

\section{Figure 16. New extensions of collective wage agreements have declined}

Number of workers covered by new extensions of collective wage agreements, in thousand ${ }^{1}$

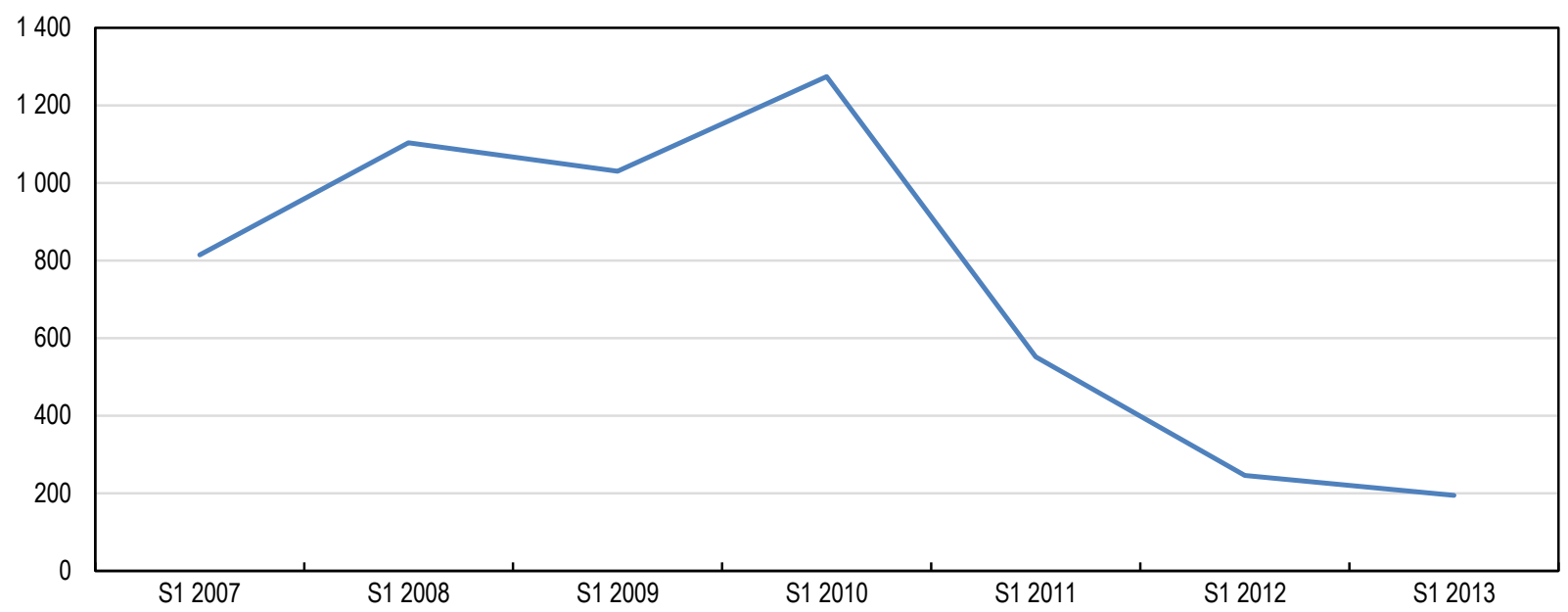

1. S1: first semester.

Source: Direção-Geral do Emprego e das Relações de Trabalho.

Firm-level analysis undertaken in Arnold and Barbosa (2014) can provide some additional insights into the effects of extensions of collective wage agreements. The results suggest that a more extensive coverage of collective wage bargaining agreements reduces firm productivity significantly. One possible explanation for this effect could be that by curbing entry, administrative extensions reduce the competitive pressures on incumbent firms and hence their incentives to improve production efficiency. Since more productive firms are more likely to become successful exporters, wage extensions are likely to have a negative effect on export performance as well.

\section{Employment protection legislation}

Recent reforms introduced in 2011, 2012 and 2013 have noticeably reduced employment protection for permanent and temporary contracts. Severance pay for fair dismissals has been reduced from 30 to 12 days per year of tenure, with a 12-month ceiling instead of a 3-month floor, although existing contracts preserve some entitlements accrued under the old rules through a transition regime applied to existing contracts. Individual dismissals for economic reasons no longer need to adhere to a pre-defined order of seniority, while those based on worker capability have become possible in a wider range of circumstances. In both cases, the obligation to transfer the employee to another suitable position was replaced by a requirement on the employer to assess whether, in the case of suppression of a post, the employee could be transferred to a position compatible with his professional qualifications. These comprehensive reforms have substantially reduced employment protection against individual dismissals although it remains more stringent than in most OECD countries. It is already low for collective dismissals. Nonetheless, 
employment protection legislation in Portugal remains more stringent than in most OECD countries (Figure 17).

\section{Figure 17. Employment protection of permanent workers}

Scale from 0 (least stringent) to 6 (most restrictive) ${ }^{1}$

\section{A. Protection against individual dismissal}

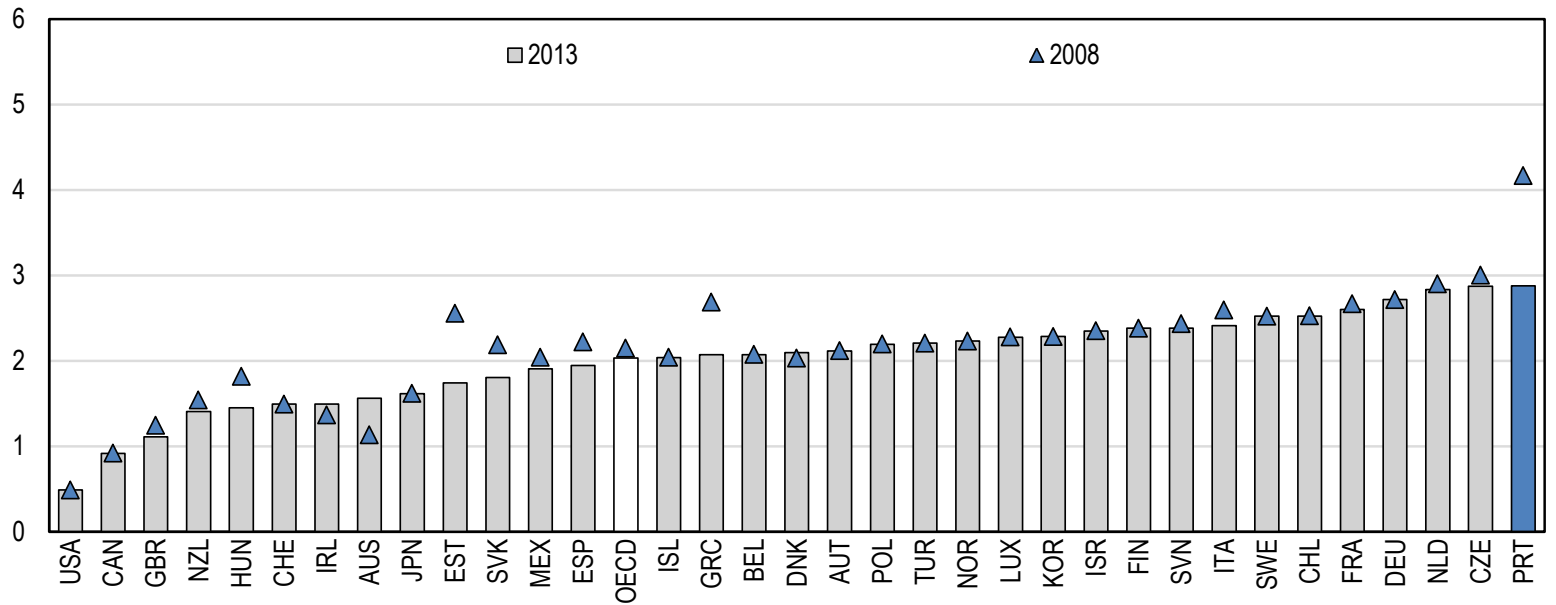

B. Protection against collective dismissal

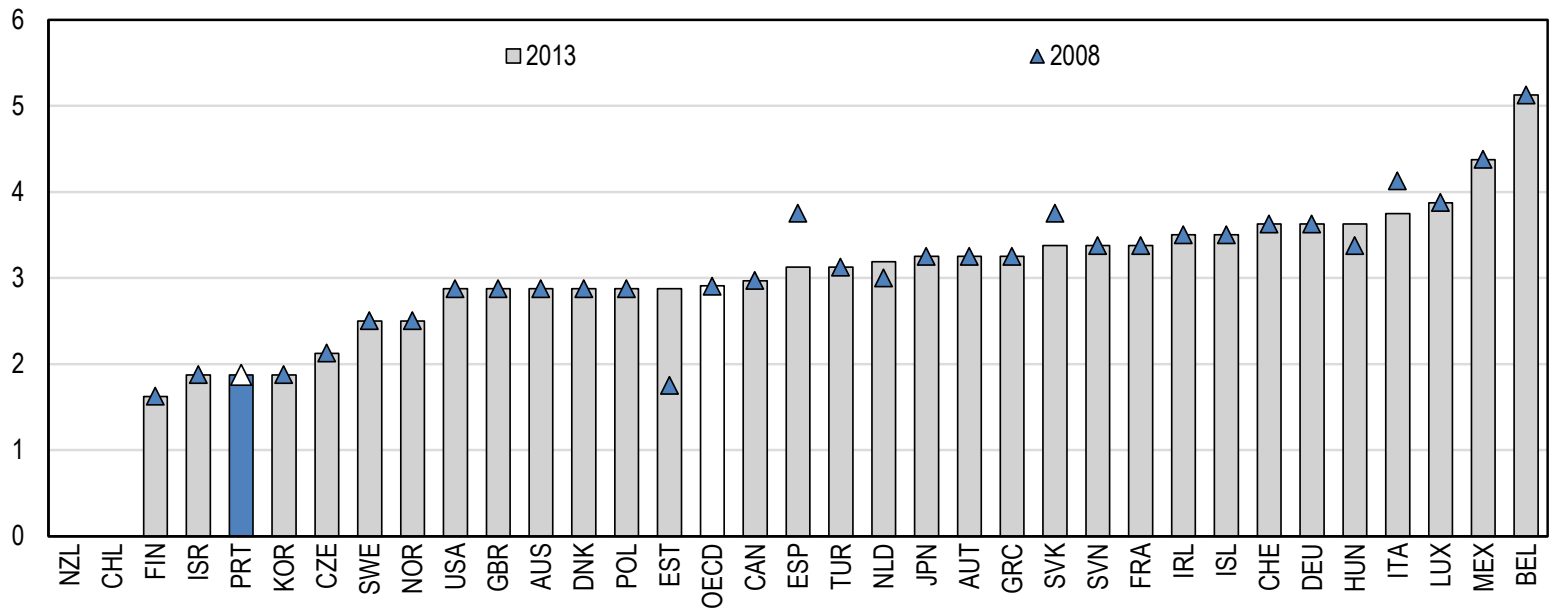

1. The indicator for collective dismissal measures additional costs and procedures involved in dismissing more than one worker compared with the costs of individual dismissal. For Chile and New Zealand the level of additional protection against collective dismissals is zero (i.e. least stringent). For Portugal only, the indicator values are preliminary calculations made for this survey using the OECD methodology and not official OECD indicators and they represent the situation at the end of 2013. The official indicator values are subject to change at the time of the next update, planned for 2018 . For most other countries, the indicators represent the situation on January 1 st 2013.

Source: OECD (2014), OECD Employment Protection Database, June and OECD calculations.

Given the substantial recent reforms implemented over the last 3 years, the immediate priority will be to assess and monitor the reform impact and the performance of labour markets. In the longer run, an issue that may deserve further attention is the discrepancy between employment protection for dismissals that are considered "fair", including dismissals due to the extinction of the job, due to misbehaviour or due to unsuitability, and those considered "unfair", which are dismissals for all other causes. Severance payments for such dismissals have not been affected by recent reforms and courts can mandate firms to reinstate the 
worker, except in the case of small firms. The strong sanctions in the case of unfair dismissals could reduce the quality of matching between jobs and workers and reduce the performance incentives for tenured workers, both of which can reduce productivity. However, changing the rules for unfair dismissals may require changes to the constitution.

\section{Promoting skills development}

The effect of labour on the competitiveness of companies is not only a question of cost and flexibility, but also of the quality and the skill set of the workforce. Educational attainments remain low, and further improvements in skills are crucial for enhancing productivity and competitiveness, but also innovation activities. Only 58\% of people aged 25-34 had attained upper secondary education in 2012, compared with an OECD average of $82 \%$ (Figure 18). Tertiary education attainment rates are also over one third below the OECD average. Average performance of 15-year olds in the 2012 PISA assessment remains significantly below the OECD average, but has improved over the years. Compulsory education continues up to the 12th grade (18 years old) instead of 9th grade since 2012. Nevertheless, many children still do not make satisfactory progress at school. Grade repetition is frequent, and this has proven an ineffective and costly way to support poorly performing students. Around one third of students had repeated grades at least once by age 15 in 2012. Providing extra teaching time for students who fall behind and taking into account their needs so that they can catch up with their peers is a much better way of supporting those with learning difficulties than grade repetition, and is not necessarily more costly. With more than $20 \%$ of students leaving school early, Portugal still has one of the highest drop-out rates in the European Union, and reducing grade-repetition could help to build on the substantial improvements that Portugal has made in this area over the last decade.

Figure 18. Upper secondary and tertiary attainment for 25-34 year-olds

Per cent, $2012^{1}$

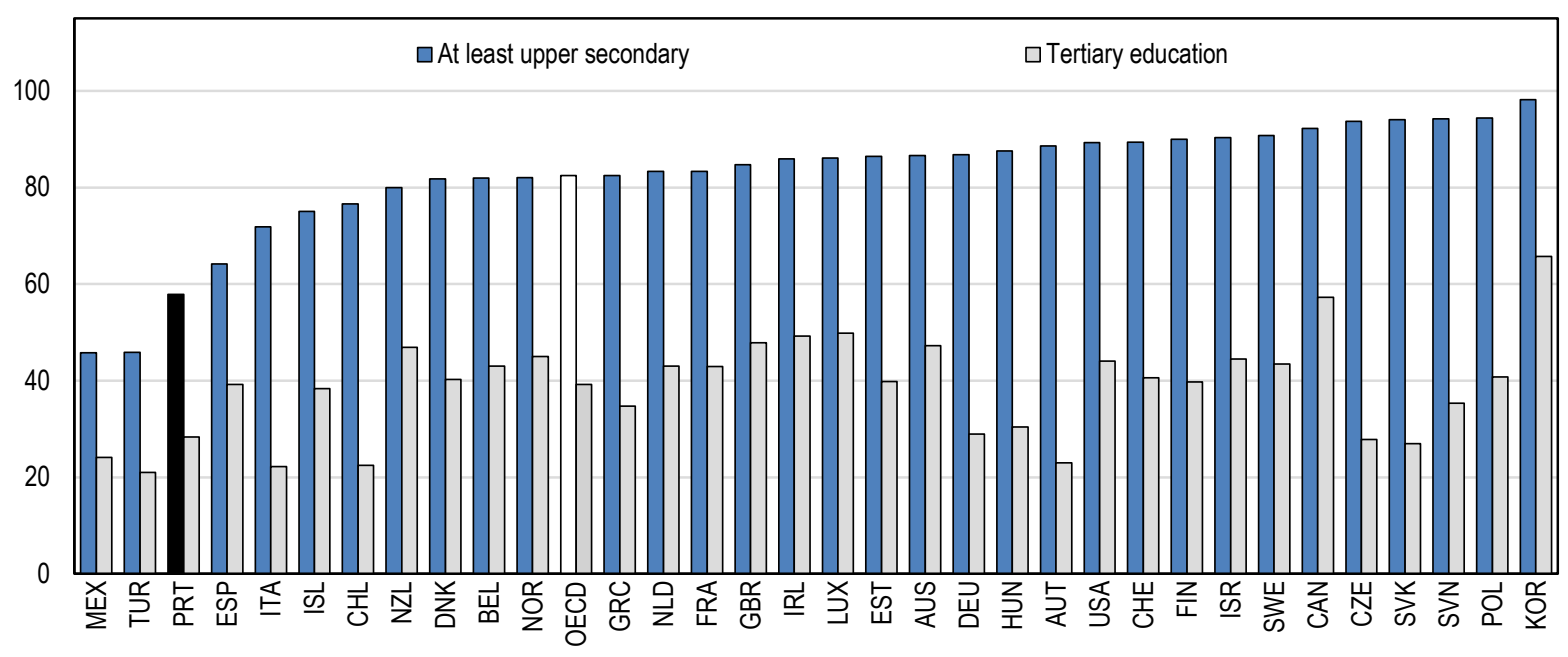

1. 2011 for Chile. The category of at least upper secondary education covers upper secondary, post-secondary non-tertiary education and tertiary education.

Source: OECD (2014), Education at a Glance 2014.

The structure of government spending on education should be improved further. While the smaller size of classes can explain part of the differences in salary costs compared to the OECD average, analysis suggests that better qualified teachers have a greater impact on students' outcomes than small classes, especially in secondary and tertiary education. Improvements could also be achieved through greater use of 
school, teacher, and student evaluation tools to provide targeted and timely support where it is most needed. This requires a greater focus on student progress in the evaluation and assessment system, as initiated for the 2012-13 school year; collecting information over time on individuals and cohorts; instituting development appraisal to complement the current accountability-focused appraisal for teachers; and shifting resources towards a system-wide analysis of outcomes.

Gearing vocational education better to the needs of the economy

The vocational education and training (VET) system has been subject to a number of reforms, and enrolment has risen by over 50\% between 2011 and 2013. Around 150000 students are currently enrolled in these courses, which include mandatory in-company training. Nonetheless, VET could be better aligned with labour-market needs. In the past, VET has suffered from a lack of continuity in policy strategies which has led to the views and opinions of private actors and social partners not being sufficiently heard and did not create the best incentives for aligning educational offers to labour-market needs. The Government should foster a close partnership with business to ensure that training is relevant to the labour market and students can have substantial workplace learning experience. The authorities should also ensure that VET programmes provide basic business skills and preparation for self-employment, as well as help to cope with the demands of new industries and technologies. Recent policy initiatives, such as the National Youth Guarantee Plan (Plano Nacional do Programa Garantia Jovem, 2013), which aims to help everyone under the age of 25 to find employment, continued education, an apprenticeship or a traineeship within four months of becoming unemployed or leaving the formal education system, shows promise. Nevertheless, it will be important to continue tracking the labour market outcomes of training participants and adjust programmes accordingly. Shorter training options such as the 2-year polytechnic course planned for the 2014 academic year can be interesting intermediate solutions between VET and academic qualifications.

The experience of other OECD countries might help Portugal to overcome some of the main challenges in building up a more effective VET system. Denmark and Switzerland illustrate the importance of effective employer engagement: in these countries, at least $75 \%$ of students enrolled in VET programmes spend at least half of the programme in the workplace. As a result of this employer involvement, students and their families see the labour market value of the programme, while employers benefit from lower hiring costs and productivity gains in the long run.

Supporting adult learning

Education reforms take time to have an impact and a country can also develop the skills it needs by encouraging and enabling people to learn throughout their lives. Adult training is particularly valuable in Portugal which has made progress in catching up with respect to the education that young people receive nowadays, while the skills of its current labour force still reflect a legacy of low educational achievements. Improving the skills of those already in working age will not only ensure more rapid progress of workforce skills, but it can also improve equity by enhancing the earnings opportunities of those who did not have access to a quality education during their youth. Finally, establishing a skills-oriented migration policy for Portugal with the aim to both fill local skills gaps but also to tap into the skills pool of the large Portuguese diaspora should also be part of the tool box for addressing skill shortages in specific areas.

Portugal is taking several initiatives to tackle these challenges and is currently conducting an OECD Skills Strategy country project, which aims to provide a strategic assessment of the national skills system in Portugal. The diagnostic phase aims to identify the main challenges in developing, activating and using skills in Portugal; the results will be published in early 2015. The project will help forge a stronger link between the economic recovery agenda and skills policies. 


\section{Policies affecting productivity and export performance}

\section{Taxes and administrative burdens}

Portuguese companies are taxed more than in the average OECD country, and this can have negative consequences for their cost competitiveness and for the pre-tax returns required to make an export operation worthwhile. High taxes on companies can also have negative effects on competition, for example by reducing the incentives for risk-taking or for productivity-enhancing investment (Arnold et al, 2011). The tax wedge on labour inputs, for example, which includes also social security contributions, was considerably above the OECD average in 2013 (Figure 19). Although in the current fiscal situation the scope for cutting taxes is limited in the short term, there is nonetheless scope for making the tax system more conducive to productivity growth and supportive of exports by shifting the tax structure away from labour income taxes and social security contributions (SSC) towards less distorting taxes (Arnold et al., 2011). Revenue losses from these measures could be compensated by improving the efficiency of the tax system, including by further reducing tax expenditures and tax evasion. Successful efforts to reduce evasion and tax fraud have been made since 2012, and these efforts should be continued.

Figure 19. Marginal tax wedge

Per cent of total labour costs, $2013^{1}$

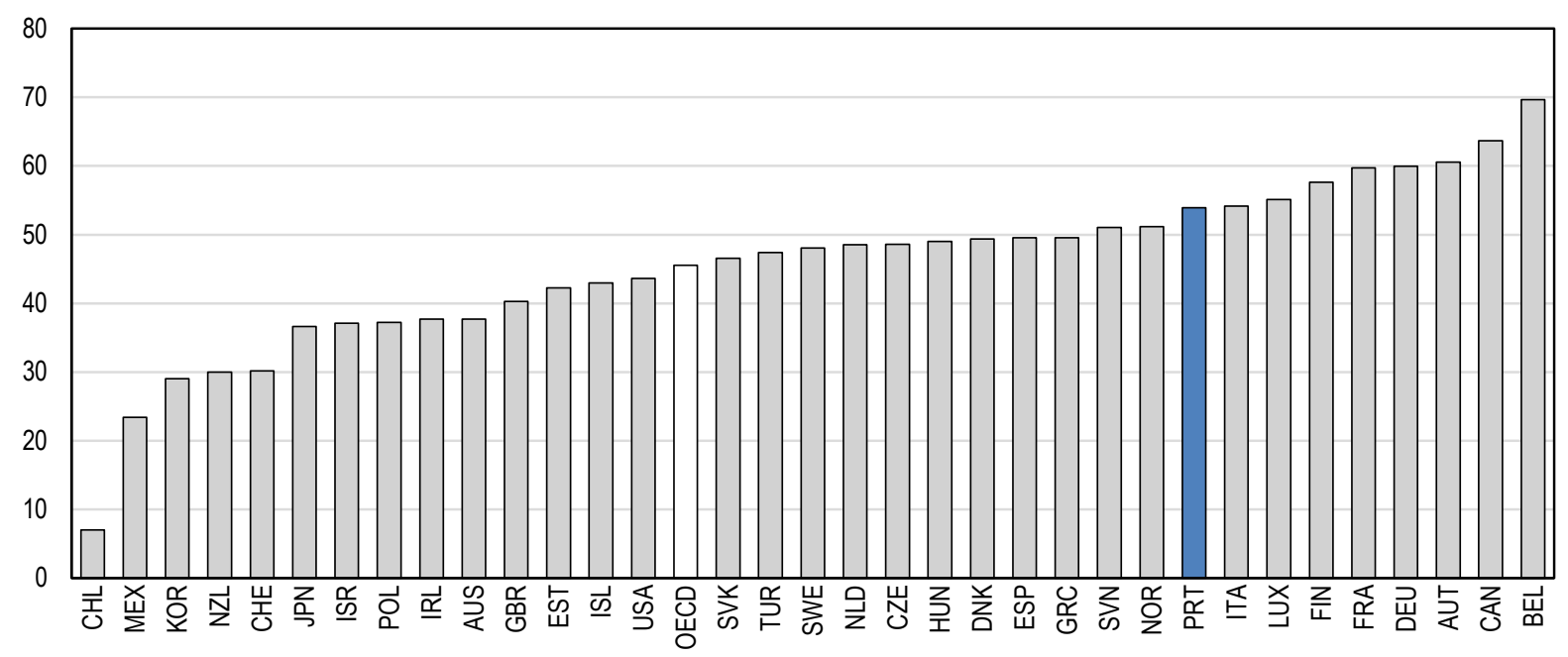

1. Income tax plus employee and employer contributions less cash benefits for a single person without children at the income level of the average worker.

Source: OECD (2014), Taxing Wages 2014.

Taxes on corporate income reduce competitiveness, and can also affect the productivity of firms in several ways (Arnold et al, 2012). First, higher corporate taxes may reduce incentives for productivityenhancing innovations by reducing their post-tax returns. Second, higher corporate taxes may reduce the incentives to invest in physical capital by increasing investment costs. If new vintages of physical capital embody technological progress, this can also have a direct effect on TFP. Finally, compliance with taxes also draws directly on firms' resources, and dealing with taxes can consume substantial amounts of manpower. From the perspective of a potential exporter, the extra burden imposed by taxes can affect the decision on whether or not to export. Given that there are typically sunk costs involved in starting up export activities, which are not incurred for domestic sales, export projects may require higher expected returns to be realised than domestic sales, and these expected returns may be diminished if the tax burden 
is high, particularly if it is higher than for potential international competitors. Micro-level evidence presented in Arnold and Barbosa (2014) suggests that the tax burden on corporations is negatively related to productivity, supporting the view that reducing the tax burden on companies could improve both productivity and export performance.

The Portuguese authorities undertook a broad corporate income tax reform in 2014, comprising a rate reduction, changes to the tax base affecting investment incentives and simplification measures aimed at reducing compliance costs. With a top marginal rate of $31.5 \%$ for large firms, the statutory tax rates are still high in European comparison. Looking at effective tax rates, which take into account differences in the tax base and other specific tax rules not reflected in the statutory rate, Portugal appears in the upper range of European comparator countries as well, even after the recent reform (Figure 20). This holds both for the marginal and the average effective tax rate. Going forward, future rate reductions to the range of 17-19\% and an elimination of a $1.5 \%$ municipal surcharge are currently being discussed. Budget permitting, this would be a useful medium-term objective.

Figure 20. Effective corporate tax rates

Per cent, 2012

A. Effective marginal tax rates

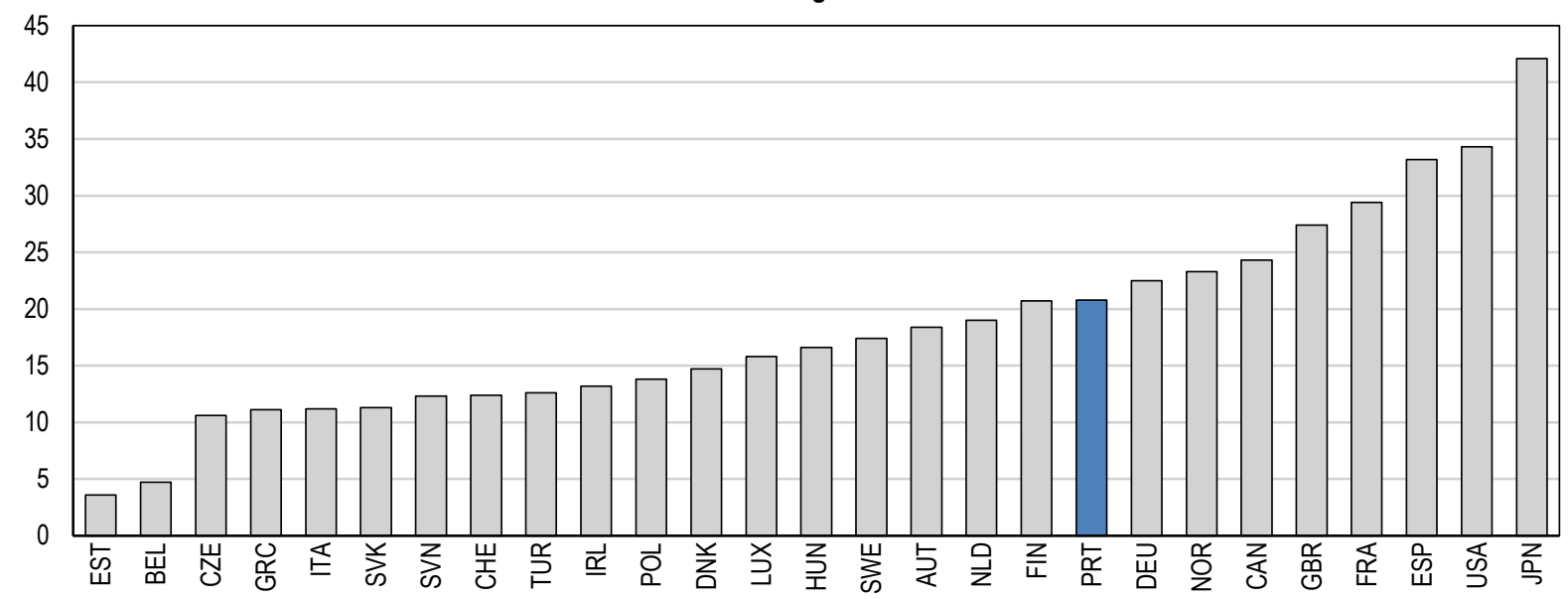

B. Effective average tax rates

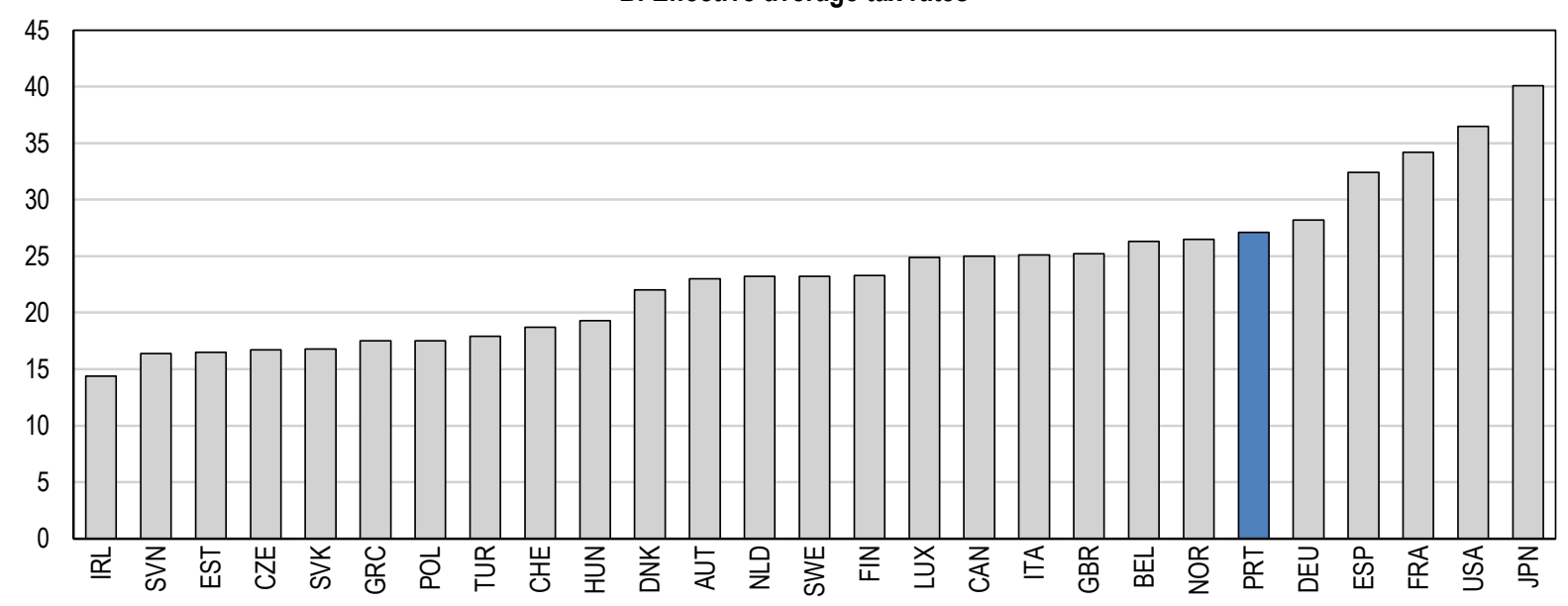

Source: Spengel C., C. Elschner and D. Endres (2012), "Effective Tax Levels Using the Devereux/Griffith Methodology", Project for the EU Commission TAXUD/2008/CC/099, Final Report 2012, Centre for European Economic Research (ZEW), Mannheim, October. 
The reform has lowered the tax burden on all but Portugal's largest companies, as firms with taxable profits above EUR 35 billion face a new surcharge. This surcharge aims at targeting economic rents in non-tradable sectors, on the premises that the majority of the country's largest companies are indeed in the non-tradable sector. While there is evidence of significant rents in some sheltered sectors, and the options for reducing them in a more direct way are facing legal and political limits, attempts to reduce sector imbalances through a differential effective taxation based on firm size constitute a fairly poor targeting. By putting very large firms at a disadvantage, they also aggravate the skewed size distribution of Portuguese firms, and create disincentives to consolidation and exploiting economies of scale. Since exporters are known to be larger than non-exporting companies, they may have been put at a relative disadvantage by the reform. Of Portugal's 50 strongest exporters, 27 had profits above EUR 35 million in 2012 and these firms accounted for $18 \%$ of exports. This differential treatment of large firms with respect to the statutory corporate tax rate should not be made permanent.

Beyond changes to the statutory corporate tax rate, the reform has also affected the definition of the corporate income tax base through an extension of loss carry-forward provisions. More generous loss carry-forward provisions enhance firms' incentives for risk taking, with possible benefits for productivity. If profits are taxed at a higher rate than losses are compensated, firms pay more in the event the risky project is successful than the taxes they save in the event it is unsuccessful. In general, innovative projects that test new ideas on the market or first-time exporting activities tend to be riskier than other projects. The 2014 reform has extended the possibility to deduct losses from earlier years from current taxable income from 5 years to 12 years, even though at the same time the loss carry-forward has been limited slightly from $75 \%$ to $70 \%$ of losses incurred. This extension will strengthen incentives for more risky investments with a possibly long amortisation horizon, which is a welcome measure. In addition to this change, the traditionally generous tax treatment of company vehicles has been reduced, although the tax rate on vehicles with an acquisition cost below EUR 25000 is still significantly below the personal income tax rate, and there is no compelling economic reason why the fringe benefit of a company vehicle should be taxed lower than other income.

Portugal also has a more onerous tax administration than other countries. Although there is not one single method of measuring tax compliance costs, the widely used World Bank Doing Business Indicators imply that they are high in Portugal (World Bank, 2014). According to this source, Portugal ranks 81st out of 189 economies with respect the overall ease of paying taxes. The time required to comply with tax obligations, for example, is more than 50\% higher in Portugal than in the OECD average. Empirical results presented in Arnold and Barbosa (2015) confirm the negative effect of high tax compliance costs on firm productivity, and hence export prospects. The more time it takes to comply with taxes, the lower the productivity of firms, particularly in sectors with more taxable profits.

For small and medium companies with income below EUR 200000 and assets below EUR 500 000, a simplified tax regime is being instated, with fixed sector-specific tax rates on turnover on the basis of previous studies. While this simplified regime will reduce compliance costs for SMEs, it also creates incentives to stay small and incentives towards vertical integration, which may distort the organisation of the value chain by taxing the use of intermediate inputs from outside the firm at a higher rate.

Portugal has made progress in enhancing tax compliance. A Large Taxpayer Office (LTO) was established at the end of 2012, and effective arrangements for the sharing of information between tax authorities and the social security administration have now been set up, in addition to the hiring of 1000 new tax auditors. Official estimates suggest that 10-15\% of the increase in tax revenues in 2013 was due to lower tax avoidance. The authorities should consider build on these efforts by rolling out more LTOs across the country and further improving information sharing between different parts of public administration. 
Substantial progress has been made in the reduction of administrative burdens for starting a business. The "Zero Licensing" programme aims to reduce or abolish ex-ante licensing requirements for some services and industrial projects. It has recently been extended to large retail outlets, restaurants and a few additional services industries. For large retail outlets, this reform replaces a number of municipal license requirements with a single license obtained from the central administration, and significantly reduces the license fees, which could go up to EUR 1 million in the past. These are important steps in the right direction, but going forward, the implementation of the programme could be further enhanced. Beyond those licensing issues for which a reduction of administrative burdens through the programme is planned but not yet implemented, the authorities are advised to explore further areas into which this approach could be extended, with a view to reducing administrative burdens further. The case for lowering administrative burdens to improve the productivity of firms is indeed strong, and the empirical work in Arnold and Barbosa (2015) confirms a significant reduction of firm productivity as a result of higher administrative burdens in Portugal.

\section{Judicial reform to reduce the cost of enforcing contracts}

The ability of firms to enforce contracts with clients, suppliers, debtors, creditors and employees depends on the efficiency of the civil judicial system, and lengthy or cumbersome procedures of dealing with courts can substantially add to firms' costs and reduce their productivity. The empirical analysis in Arnold and Barbosa (2014) confirms this reasoning. The firm-level regressions find a significant link between the number of procedures required to enforce a contract on one hand, and firm productivity on the other.

Portugal's civil justice system continues to be characterised by difficulties in managing court backlogs and high trial lengths, particularly in first instance courts which deal with contract enforcement. The backlog of over 1.5 million court cases has come down slightly recently, but most of this progress is due to a lower number of incoming cases rather than genuine progress in case resolution (Figure 21). Reasons behind the decline in new litigation include a reform of the fee structure and a change in value-added tax (VAT) rules that had caused excess litigation in the past. Portugal spends a comparatively large share of GDP on its court system, but seems to be getting a poor return on these resources. One possible reason may be that the budget allocation is highly skewed towards wages, while investment in information and communication technology is fairly low (Figure 22). Excessively complicated and stringent procedures also seem to play a key role. A new civil procedure code has been able to address some of these shortcomings by giving greater process independence to judges, a stronger focus on substance rather than form and a reduction of the number of appeals and allowing for mediation and out-of-court settlements at different stages of a civil process.

While the new code of civil procedure is a move into the right direction, implementation of judicial reform seems to be lagging. For example, the introduction of specialised courts has been found to reduce trial lengths (Palumbo et al., 2013), but the specialisation of courts is likely to make a real difference only if these courts are staffed with specialised judges, which is not the case in Portugal. There also seems to be an imbalance towards too many superior courts as opposed to courts of first instance, and in favour of certain regions, although a recent redefinition of the judicial map may be able to address some of this imbalance. Judges continue to be bound by overly detailed procedural codes, but giving them more discretion in case management should go along with better incentive mechanisms so that judges move up the court hierarchy based on performance rather than seniority. 
Figure 21. Backlogs in the judicial system remain sizeable

Number of pending court cases, in million ${ }^{1}$

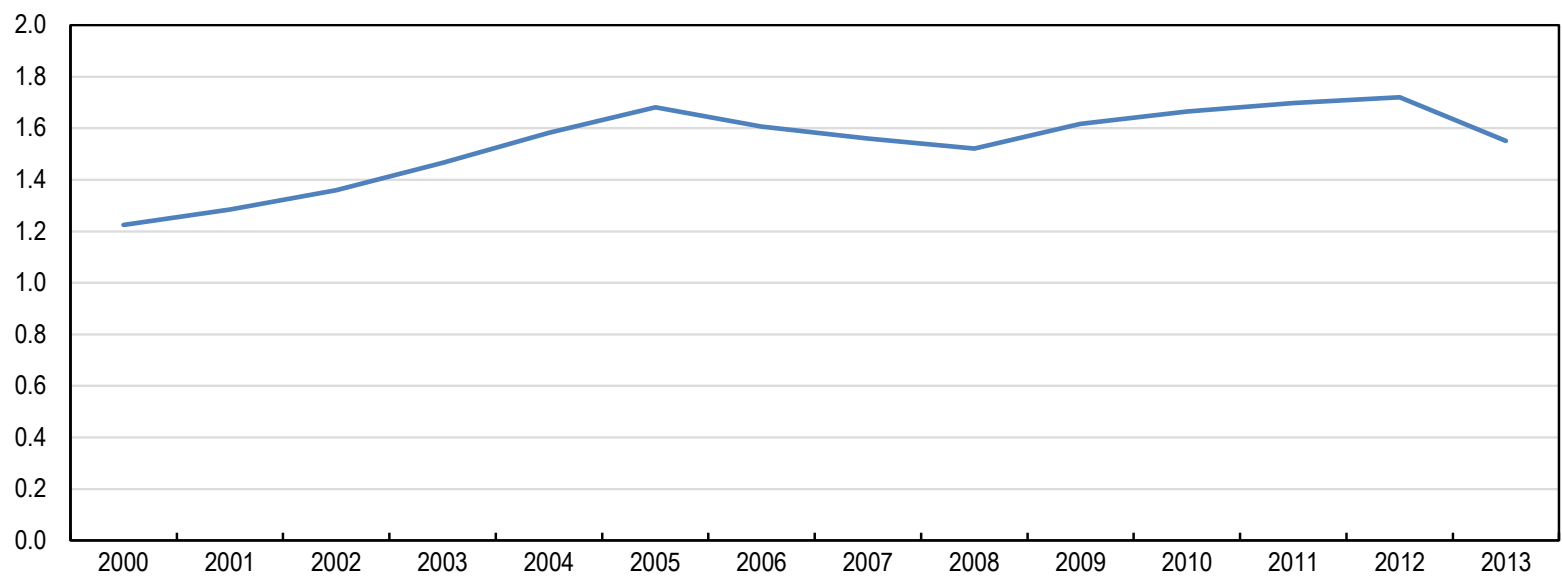

1. Values for 2013 are preliminary.

Source: Ministry of Justice, PORDATA.

Figure 22. Resources devoted to court system ${ }^{1}$
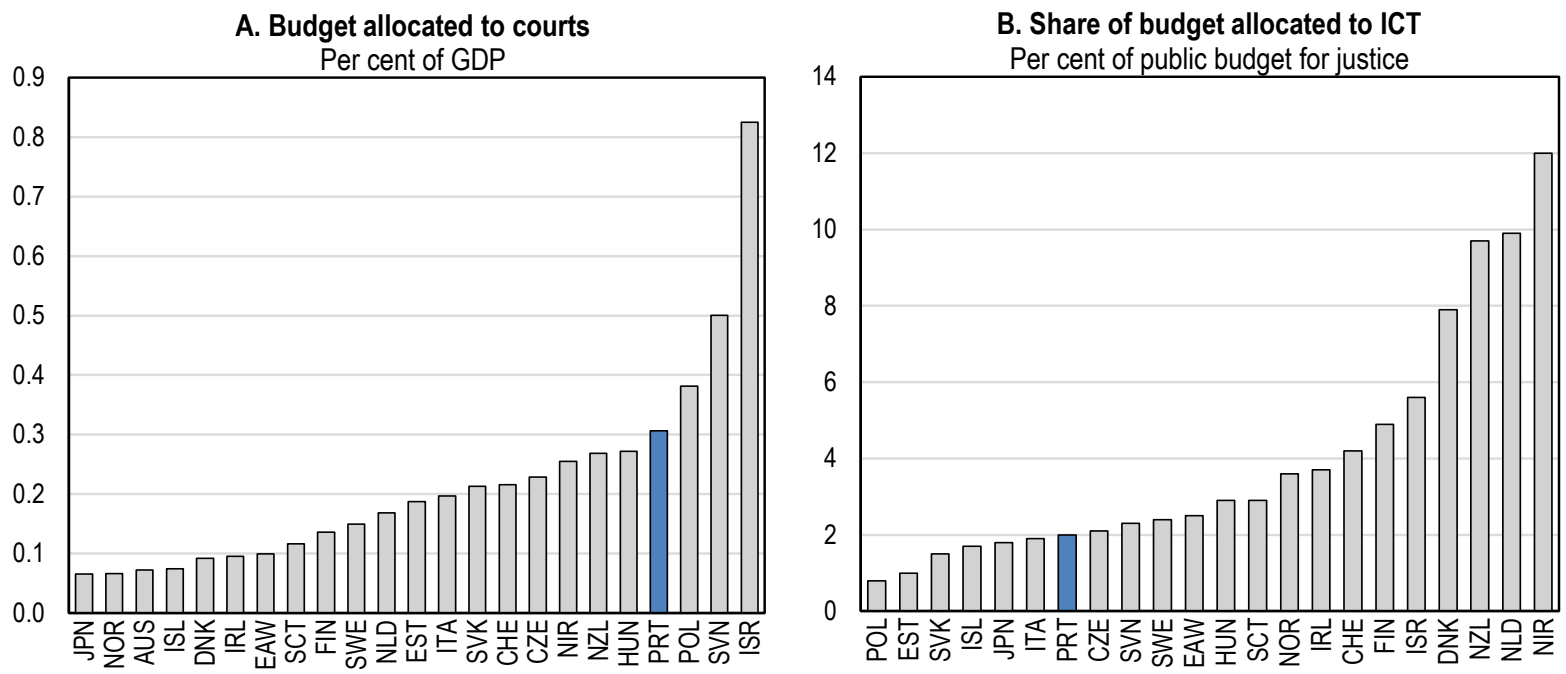

1. EAW: England and Wales. NIR: Northern Ireland. SCT: Scotland. ICT: Information and Communication Technology.

Source: Palumbo, G., et al. (2013), "Judicial Performance and its Determinants: A Cross-Country Perspective", OECD Economic Policy Papers, No. 5, OECD Publishing.

\section{Innovation and technology}

The innovation performance of Portuguese industry is weak, as is investment in knowledge capital more generally, including software and databases, innovative property and economic competencies. Both innovation and knowledge capital are key to creating value and enabling product differentiation, which can help sustain market shares against wage-based competition. One indicator for this low performance is that companies based in Portugal file less than a third of patent and trademark applications filed by the average OECD country (Figure 23). 
Figure 23. Patents and trademarks

Average number per million population, 2009-11 1

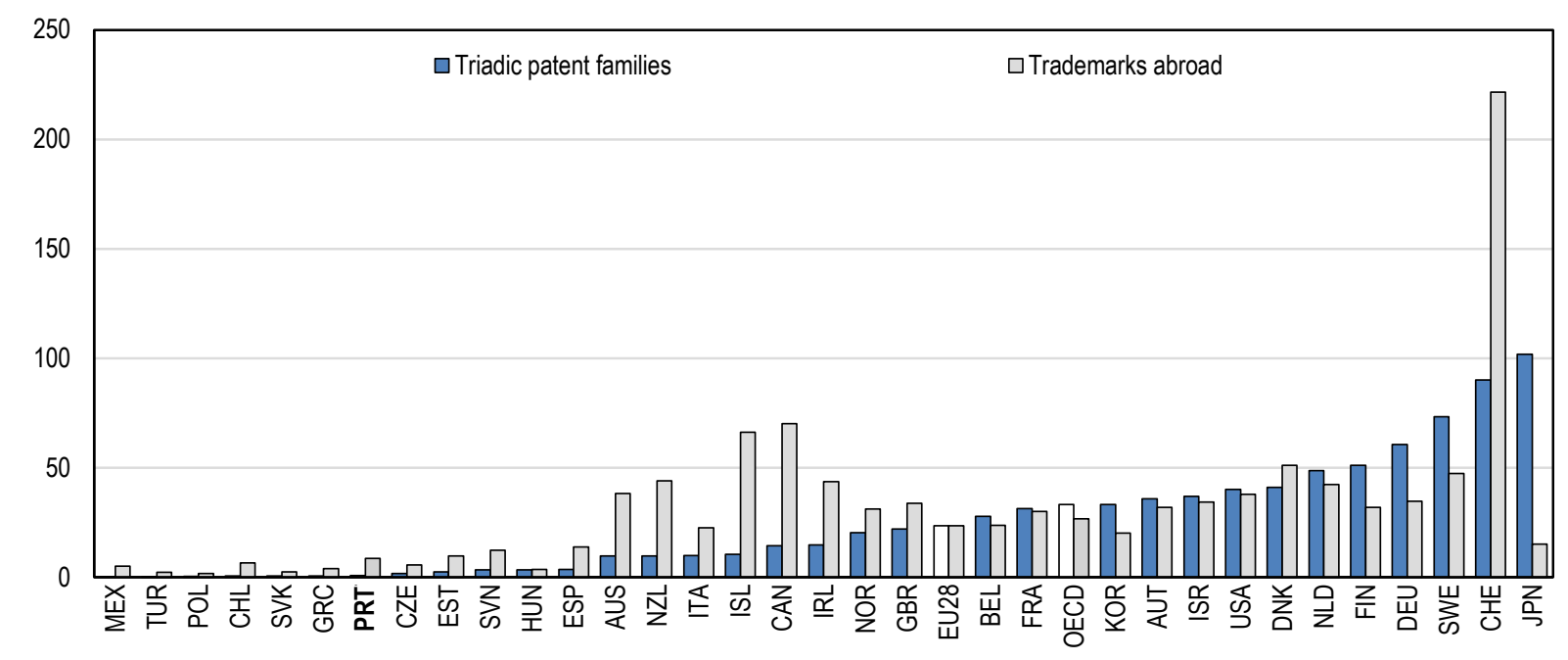

1. Triadic patent families are defined as patents applied for at the European Patent Office (EPO), the Japan Patent Office (JPO) and the United States Patent and Trademark Office (USPTO) to protect a same invention. Trademarks abroad correspond to the number of applications filed at in the US, EU and Japan, corrected the relative average propensity of other countries to file in those three offices.

Source: OECD (2013), OECD Science, Technology and Industry Scoreboard 2013.

Portugal also spends less than others on the generation of knowledge-based capital. Overall research and development (R\&D) expenditures are significantly below the OECD average and have been declining since 2009, a trend that may place some of the recent progress in Portugal's innovation capacity at risk. R\&D efforts are particularly low when focusing only on expenditures in business enterprises, which amount to less than half the OECD average relative to GDP (Figure 24, Panel A). R\&D taking place in companies is arguably closer to market demands, and hence more likely to feed in to commercial results

. The low share of business $R \& D$ reflects the fact that a large share of $R \& D$ expenditures occurs in universities, with often weak linkages to industry (Figure 24, Panel B). The weakness of these links is reflected, for example, in the low number of new high-tech firms originating from academia but also in the large number of $\mathrm{PhDs}$ that remain in universities rather than joining the private sector. Commercial spinoffs from what were originally academic projects have played an important role for the development of industrial clusters in some countries, notably in the United States where several high-tech clusters have emerged around universities and researchers have created important start-up ventures (Capart and Sandelin, 2004; Sandelin 2003; Harayama, 1998). A recent revision of university statutes is meant to facilitate exchanges between academia and business by allowing university teachers to move to companies to develop projects. A Strategic Programme for Entrepreneurship and Innovation seeks to promote knowledge transfers from academia to industry through several channels. These are steps into the right direction, but the lack of an effective connection between research efforts made at universities and their commercialisation in the private sector remains a serious issue.

One main area for policy action includes measures to improve the ability of university tech transfer offices (TTOs) to link with industry, inter alia through support for academic patenting. OECD evidence on university technology transfer suggests that the effectiveness of TTOs in linking with business depends on critical mass and expertise, and appropriate organisational structures and incentive schemes. The weak performance of TTOs in many countries has led to efforts to consolidate operations and develop new 
organisational models and incentives that could be useful examples for Portugal. One example is the Idea Evaluation initiative at Chalmer's University of Technology in Sweden, which brings together entrepreneurs and senior academics to evaluate the commercial potential, including the business plans, of student inventors and entrepreneurs. In Finland, the Aalto Centre for Entrepreneurship (ACE) offers innovation, marketing and start-up services for Aalto University researchers, students and other stakeholders. In addition, it facilitates innovation and growth entrepreneurship by developing research and education in these fields across all Aalto schools.

Figure 24. Research and development (R\&D) expenditures

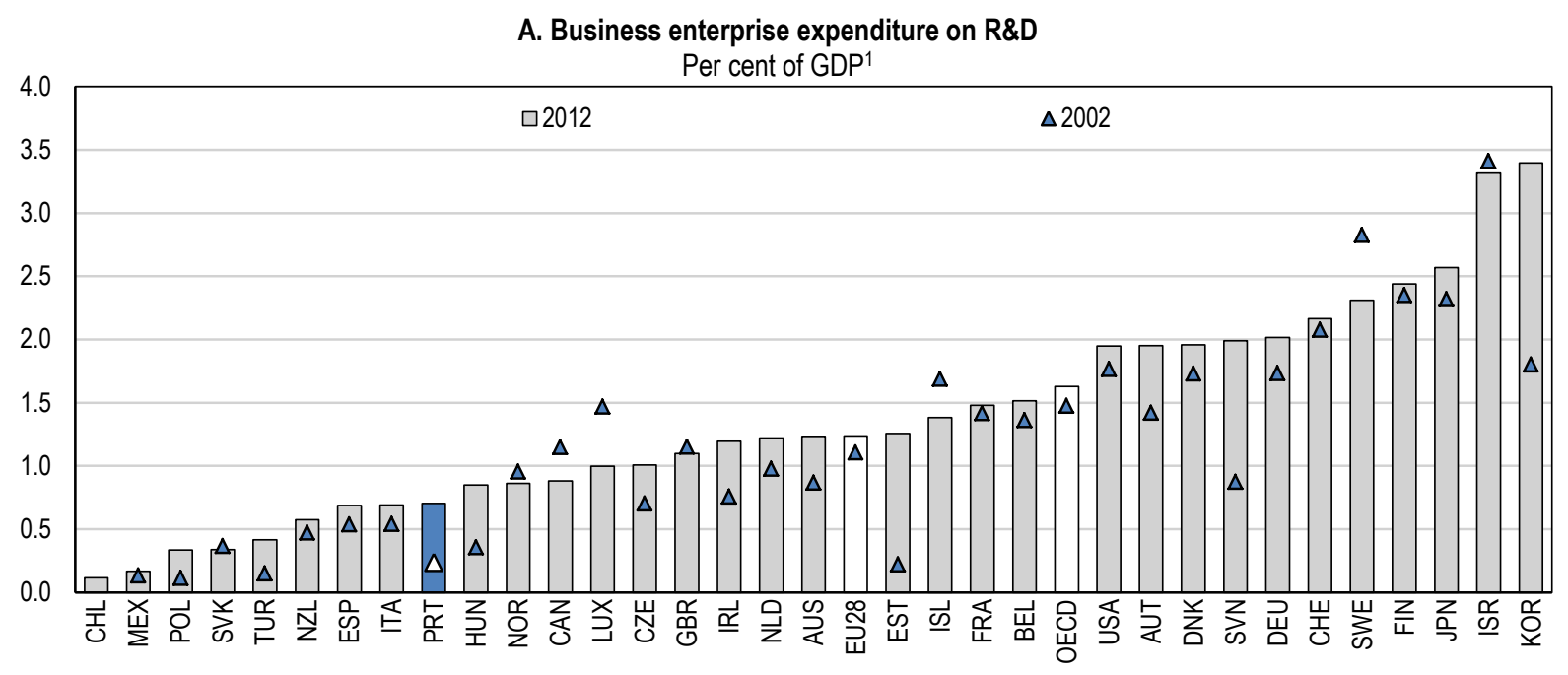

B. R\&D expenditure by sector

Per cent of gross domestic expenditures on R\&D, $2012^{2}$

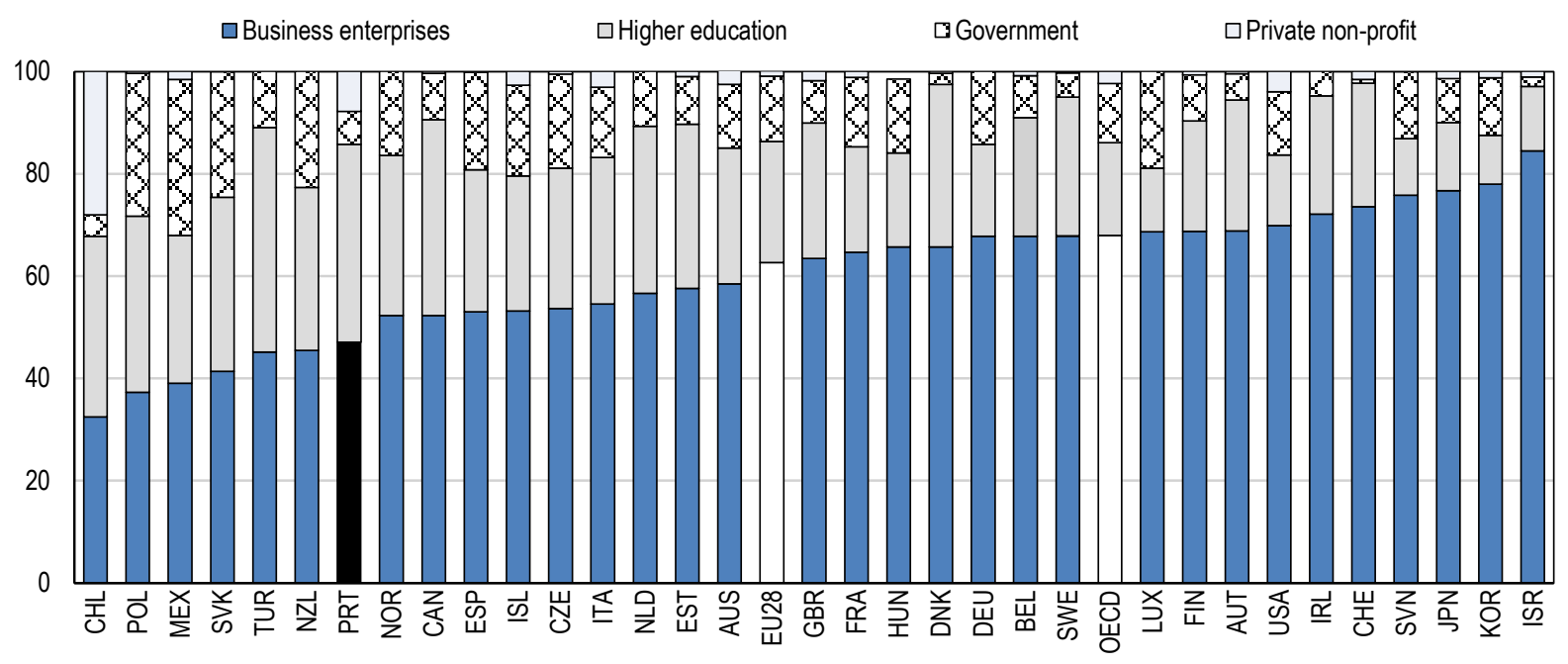

1. 2011 instead of 2012 for Australia, Iceland, New Zealand and Mexico. 2003 instead of 2002 for Luxembourg, New Zealand and Sweden. 2004 instead of 2002 for Switzerland.

2. 2011 for Iceland, Mexico and New Zealand. 2010 for Australia. 2008 for Switzerland. For Israel, defence R\&D is partly excluded from available estimates. For Hungary, total GERD combines survey data and data from the central budget on R\&D support. It includes R\&D expenditures that cannot be attributed to a specific sector on a performance basis. For the Netherlands, expenditures in the private non-profit (PNP) sector are included in the government sector. For the Slovak Republic, defence is excluded from the government sector. For the United States, capital expenditures are excluded from R\&D performed in the business, higher education and PNP sector and government is federal or central government only.

Source: OECD (2014), Main Science and Technology Indicators (database), July. 
Public support for business R\&D and innovation is mostly through tax credits, while other OECD countries tend to rely on a more balanced mix between direct support for business R\&D and R\&D tax credits. Portugal spends almost $0.1 \%$ of GDP on R\&D tax credits, which situates it $10^{\text {th }}$ out of 32 countries on this issue (Figure 25), and the use of R\&D tax credits has grown significantly over the last years, particularly since 2006 . By contrast, Portugal spends only $0.03 \%$ on direct support to business R\&D, which is slightly less than half the OECD average.

Figure 25. Public funding for business R\&D

Per cent of GDP, $2011^{1}$

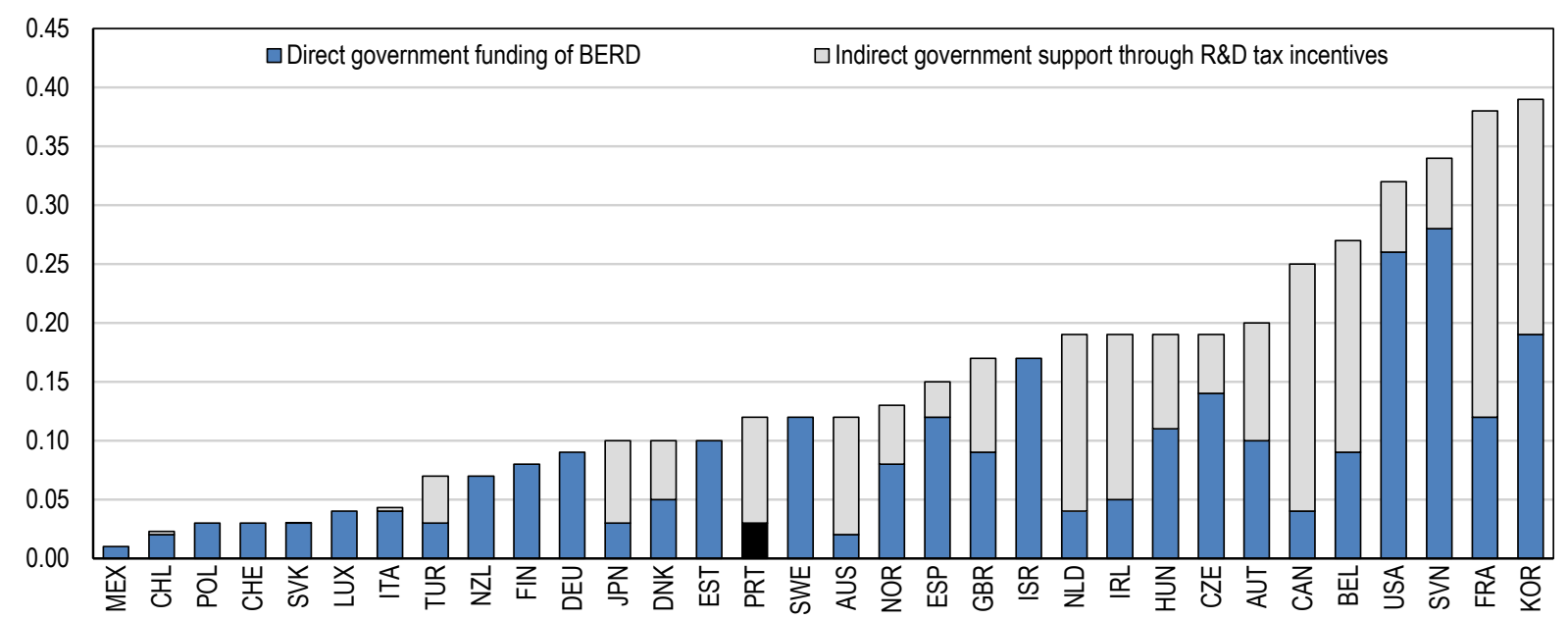

1. 2010 for Australia, Belgium, Brazil, Chile, Ireland, Israel and Spain. 2009 for China, Luxembourg and South Africa. 2008 for Switzerland. For Israel data on tax incentive support are not available. This is an experimental indicator. International comparability may be limited. For more information, see www.oecd.org/sti/rd-tax-stats.htm. BERD: Business enterprise expenditure on research and development. R\&D: Research and development.

Source: OECD (2013), OECD Science, Technology and Industry Scoreboard 2013.

While R\&D tax credits can be an effective tool to foster innovative activities, their design can also have the unintended side effect of favouring incumbent firms, and by doing so they can act as an implicit barrier to market entry and slow down the reallocation of resources towards more innovative entrants (Bravo-Biosca et al, 2013). In cross-country comparison, more generous R\&D tax credits are associated with a higher share of stagnant firms and a lower share of shrinking firms (Bravo-Biosca et al, 2013). The reason for this is that tax credits are usually counted against taxable profits, and new entrants typically lack taxable profits for a significant number of years.

Some countries mitigate these effects by allowing tax credits to be converted into cash refunds, such as Australia, Canada, Denmark, Norway, or the United Kingdom. Highly generous loss-carry forward provisions can also help to level the playing field for new entrants, and some countries are allowing losscarry forward for R\&D tax credit with an indefinite duration (Australia, Belgium, Ireland, United Kingdom), or for 20 years in the case of the United States (Andrews and Criscuolo, 2013). Portugal, in contrast, does not allow refunds of $R \& D$ tax credits and the carry-forward period for R\&D expenditures is limited to 8 years. In this setting, new entrants are likely to face significant disadvantages vis-à-vis incumbents, particularly in a context of scarce and expensive credit. Portugal should consider allowing refunds of R\&D tax credits or alternatively extend the carry-forward period further.

Going forward, finding a better balance between tax credits and direct support may be useful, as direct support can help address specific market failures such as the lack of cooperation. Direct support can also be more beneficial for young firms facing financing constraints, it part because it can act as an approval 
stamp and may allow entrants to get easier access to market financing (Busom et al, 2012). In some cases, such as in the footwear and rubber industry, industry associations have successfully promoted joint technological centres in Portugal, often in connection with universities, and such joint efforts could be candidates for direct support measures.

\section{Recommendations for strengthening export performance}

\section{Regulation in services sectors}

- Strengthen competition in non-tradable sectors through further regulatory reform. Phase out electricity generation schemes with guaranteed prices sooner than currently planned.

- Abolish unnecessary regulatory restrictions in professional services, including exclusive rights for certain professions, regulations of prices and fees or the form of business and nationality requirements. Reduce the role of professional associations for regulating entry.

- Improve the efficiency of ports by attaching service level agreements to concession contracts and by promoting intra-port competition between terminals.

\section{Labour markets and skills}

- Promote wage bargaining at the firm level, including by abolishing administrative extensions of wage agreements.

- Continue to reduce drop-out rates from secondary education, including by reducing grade repetition and providing extra teaching time for students falling behind. Consider raising class sizes further if necessary to achieve this.

- Foster a close partnership between business and vocational education and training (VET), so that VET responds to labour market needs. Track the labour market performance of VET participants and adjust programmes accordingly.

\section{Access to finance for firms}

- Focus public support for small and medium-sized enterprise (SME) financing mostly on startups and young firms, including for alternatives to debt-financing such as venture capital and equity financing.

Taxes

- Further improve the efficiency of the tax system, including by eliminating remaining tax expenditures such as for company vehicles.

- Align the corporate tax burden on very large companies to that of other companies. Budget permitting, consider reducing the corporate tax rates in the medium term.

- Improve tax administration by rolling out more large taxpayer offices across the country and further improving information sharing between different parts of public administration. 


\section{Judicial reform}

- Reduce trial length and the backlog of pending court cases by concluding the implementation of the new code of civil procedure, staffing specialised courts with specialised judges, reducing the number of superior courts in favour of first-instance courts.

- Give more discretion to judges in case management and base their promotion on performance rather than seniority.

\section{Innovation and technology}

- Improve the links between researchers in universities and the private sector.

- Consider allowing refunds of research and development (R\&D) tax credits for loss-making firms or extending the carry-forward period.

\section{Bibliography}

Altomonte C., T. Aquilante and G. Ottaviano (2012), "The triggers of competitiveness: The EFIGE crosscountry report," Blueprints, Bruegel, No. 738, October.

Amador, J. and M. Cabral (2014), “A economia portuguesa no contexto global” in: A economia portuguesa na União Europeia: 1986-2010. Coimbra: Conjuntura Actual Editora, pp.187-228.

Andrews, D., C. Criscuolo and C. Menon (2013), "Do Resources Flow to Patenting Firms? Cross-Country Evidence from Firm Level Data", OECD Economics Department Working Papers, No. 1127, OECD Publishing.

Anyadike-Danes M., C. M. Bjuggren, S. Gottschalk, W. Hölzl, D. Johansson, M. Maliranta and A. Grinde Myrann (2014), "Accounting for Job Growth: Disentangling Size and Age Effects in an International Cohort Comparison", IFN Working Paper, No. 1019, Research Institute of Industrial Economics (IFN), Stockholm.

Arnold, J.and N. Barbosa (2015). "Structural Policies and Productivity: Evidence from Portuguese Firms", OECD Economics Department Working Papers, No. 1259, OECD Publishing.

Arnold, J. and K. Hussinger (2005), "Export Behavior and Firm Productivity in German Manufacturing: A Firm-Level Analysis". (with Katrin Hussinger). Review of World Economics, Vol. 141(2).

Arnold, J., B. Brys, C. Heady, A. Johansson, C. Schwellnus and L. Vartia (2011), "Tax Policy for Economic Recovery and Growth". The Economic Journal, 121: F59-F80.

Arnold, J., B. Javorcik, and A. Mattoo (2011), "Does Services Liberalization Benefit Manufacturing Firms? Evidence from the Czech Republic", Journal of International Economics, 85(1).

Banco de Portugal (2013), "Portuguese firms in export markets" Economic Bulletin 19(4), Bank of Portugal, Lisbon. 
Bartelsman, E, J. Haltiwanger, and S Scarpetta (2009), "Measuring and analysing cross-country differences in firm dynamics", in Dunne, Bradford, and Roberts (eds.), Producer dynamics: New evidence from micro data, University of Chicago Press.

Belke A., A. Oeking and R. Setzer (2013), "Exports and Capacity Constraints - A Smooth Transition Regression Model for Six Euro Area Countries," Ruhr Economic Papers, No. 0449, RheinischWestfälisches Institut für Wirtschaftsforschung, Ruhr-Universität Bochum, Universität Dortmund, Universität Duisburg-Essen.

Bernard, A. B., and B. Jensen (1999), "Exceptional Exporter Performance: Cause, Effect, or Both?” Journal of International Economics 47 (1): 1-25.

Bernard, A. B., and B. Jensen (2004), "Why Some Firms Export". Review of Economics and Statistics 86 (2): 561-569.

Blanchard O. and J. Wolfers (2000), The Role of Shocks and Institutions in the Rise of European Unemployment: The Aggregate Evidence, The Economic Journal 110 (462).

Bourlès R., G. Cette, J. Lopez, J. Mairesse and G. Nicoletti (2013), "Do Product Market Regulations In Upstream Sectors Curb Productivity Growth? Panel Data Evidence For OECD Countries", Review of Economics and Statistics 95(5), pp. 1750-1768, December.

Braguinsky, S, L Branstetter, and A Regaterio (2011), "The incredible shrinking Portuguese firm", NBER Working Papers, No. 17265, National Bureau for Economic Research, Cambridge, MA.

Bravo-Biosca, A, C. Criscuolo and C Menon (2013), "What Drives the Dynamics of Business Growth?", OECD Science, Technology and Industry Policy Papers, No. 1, OECD Publishing.

Bundeskartellamt (2010), Bundeskartellamt opens up the Puttgarden-R $\phi d b y$ ferry route to competition, Press release, German Competition Authority, available at http://www.bundeskartellamt.de/SharedDocs/Meldung/EN/Pressemitteilungen/2010/28_01_2010_Sc andlines.html.

Busom I., B. Corchuelo and E. Martinez Ros (2012), "Tax incentives and direct support for R\&D: What do firms use and why?," Working Papers, No. 1212, Department of Applied Economics, Universitat Autonoma of Barcelona.

Cabral, L. (2007), "Small firms in Portugal: a selective survey of stylized facts, economic analysis, and policy implications", Portuguese Economic Journal 6(1), pp 65-88.

Criscuolo, C, P N Gal, and C Menon (2014), "The dynamics of employment growth: new evidence from 18 countries”, OECD Science, Technology and Industry Policy Papers, OECD Publishing.

Delgado, M., J. C. Fariñas, and S. Ruano (2002), "Firm Productivity and Export Markets: A Nonparametric Approach"orking p Journal of International Economics 57 (2), pp. 397-422.

European Commission (2013), Ports: an engine for growth, European Commission, May 2013.

European Commission (2014), The Economic Adjustment Programme for Portugal - Eleventh Review, European Commission. 
Eurostat (2014), "Electricity prices for domestic consumers, from 2007 onwards - bi-annual data"in: Eurostat (2014). Energy statistics - prices, last update: 01-10-2014.

Guasch, J. (1996), "Lessons from Ports Reforms, in New Port Polices in Latin America and Caribbean", in Guasch, J. and L. Amargos (eds), Reforms and new port policies in Latin America, New Press, Barcelona, Spain.

Haltiwanger, J., R.S. Jarmin and J. Miranda (2013), "Who Creates Jobs? Small Versus Large Versus Young", Review of Economics and Statistics, 95(2), pp. 347-361.

ICA (The Irish Competition Authority) (2013), Competition in the Irish Ports Sector, Dublin, Ireland.

ISGEP (International Study Group on Exports and Productivity), (2008), "Understanding Cross-Country Differences in Exporter Premia: Comparable Evidence for 14 Countries", Review of World Economics, Vol. 144(4).

Levinsohn J. and A. Petrin (2003), "Estimating Production Functions Using Inputs to Control for Unobservables," Review of Economic Studies, Vol. 70 (2).

Martin, J. and S. Scarpetta (2012), "Setting It Right: Employment Protection, Labour Reallocation and Productivity," De Economist, Springer, vol. 160(2), pp. 89-116, June.

Melitz, M. (2003), "The Impact of Trade on Intra-Industry Reallocations and Aggregate Industry Productivity”, Econometrica 71 (6), pp. 1695-1726.

Melitz, M. and G. Ottaviano (2008), "Market Size, Trade, and Productivity," Review of Economic Studies, Oxford University Press, Vol. 75(1), pp. 295-316.

Nunn, N. (2007), "Relationship-Specificity, Incomplete Contracts, and the Pattern of Trade". Quarterly Journal of Economics 122 (2), pp. 569-600.

OECD (2011), Competition in Ports and Port Services, Directorate for Financial and Enterprise Affairs Competition Committee, December 2011.

OECD (2013), OECD/WTO Trade in value added (TiVa) Indicators: Portugal, OECD Publishing, available at http://www.oecd.org/sti/ind/TiVA_PORTUGAL_MAY_2013.pdf, last accessed September 2013.

OECD-WTO (2014), Statistics on Trade in Value Added. OECD and World Trade Organisation. Available at http://dx.doi.org/10.1787/data-00648-en.

Palumbo, G., et al. (2013), "Judicial Performance and its Determinants: A Cross-Country Perspective", OECD Economic Policy Papers, No. 5, OECD Publishing.

Raghuram G.R. and L. Zingales (1998), "Financial Dependence and Growth," American Economic Review 88(3), pp. 559-86.

Soares Esteves, P. and A. Rua (2013), "Is there a role for domestic demand pressure on export performance?," Working Papers, No. W201303, Banco de Portugal, Economics and Research Department, Lisbon. 
ECO/WKP(2015)75

SSPM (Secretary of State to the Prime Minister) (2014), The road to growth - a medium-term reform strategy for Portugal, Secretary of State to the Prime Minister, Portugal.

Wagner, J. (2012), "International trade and firm performance: a survey of empirical studies since 2006," Review of World Economics 148(2).

World Bank (2014), Doing Business 2014: Understanding Regulations for Small and Medium-Size Enterprises, World Bank, Washington, DC. 